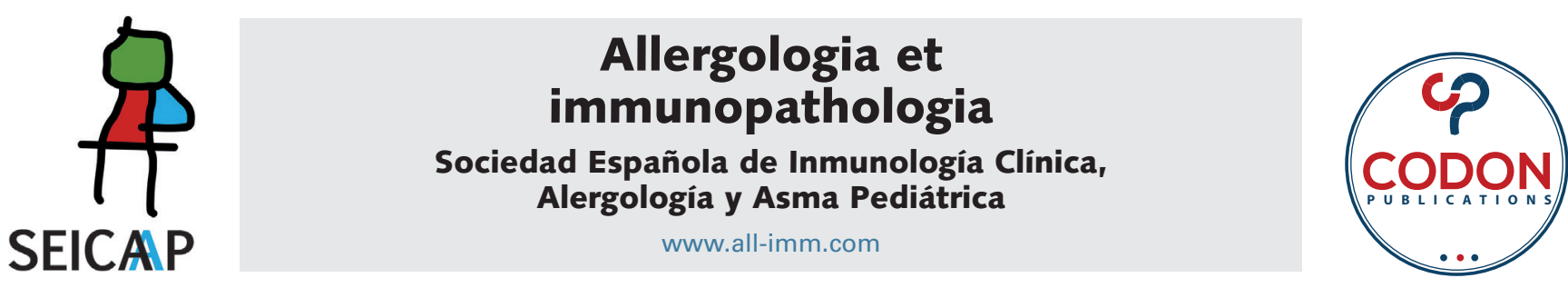

REVIEW

\title{
Eosinophil: a central player in modulating pathological complexity in asthma
}

\author{
Pulak Pritam ${ }^{a}$, Sanjeet Mannaa, Abhishek Sahu ${ }^{b}$, Shasank Sekhar Swain ${ }^{c}$, Shankar \\ Ramchandani ${ }^{\mathrm{d}}$, Sachidananda Bissoyi ${ }^{\mathrm{b}}$, Manasa Kumar Pandae , Yengkhom Disco Sing ${ }^{f}$, \\ Yugal Kishore Mohantas, Rajendra Kumar Behera ${ }^{\mathrm{b}}$, Bimal Prasad Jit ${ }^{\mathrm{b} *}$
}

\author{
a Regional Institute of Biotechnology, Bhubaneswar, Odisha, India \\ ${ }^{b}$ School of Life Sciences, Sambalpur University, Sambalpur, Odisha, India \\ 'Division of Microbiology and NCDs, ICMR-Regional Medical Research Centre, Bhubaneswar, Odisha, India \\ ${ }^{d}$ Veer Surendra Sai Institute of Medical Science and Research, Sambalpur, Odisha, India \\ eInstitute of Mineral and Material Technology, CSIR, Bhubaneswar, Odisha, India \\ ${ }^{f}$ Central Agricultural University, Imphal, India \\ sUniversity of Nizwa, Oman
}

Received 12 September 2020; Accepted 4 November 2020

Available online 1 March 2021

\section{KEYWORDS \\ eosinophil; \\ asthma; \\ allergy; \\ inflammation; \\ bronchoconstriction}

\begin{abstract}
Eosinophils are the major inflammatory cells which play a crucial role in the development of allergic and non-allergic asthma phenotypes. Eosinophilic asthma is the most heterogeneous phenotype where activated eosinophils are reported to be significantly associated with asthma severity. Activated eosinophils display an array of cell adhesion molecules that not only act as an activation marker, suitable for assessing severity, but also secrete several tissue factors, cytokines and chemokines which modulate the clinical severity. Eosinophil activations are also strictly associated with activation of other hetero cellular populations like neutrophils, macrophages, mast cells, and platelets which culminate in the onset and progression of abnormal phenotypes such as bronchoconstriction, allergic response, fibrosis instigated by tissue inflammation, epithelial injury, and oxidative stress. During the activated state, eosinophils release several potent toxic signaling molecules such as major basic proteins, eosinophil peroxidase, eosinophil cationic protein (ECP), and lipid mediators, rendering tissue damage and subsequently leading to allergic manifestation. The tissue mediators render a more complex manifestation of a severe phenotype by activating prominent signaling cross-talk. Here, in the current review with the help of search engines of PubMed, Medline, etc, we have tried to shed light and explore some of the potent determinants regulating eosinophil activation leading to asthma phenotype.

(c) 2021 Codon Publications. Published by Codon Publications.
\end{abstract}

${ }^{*}$ Corresponding author: Bimal Prasad Jit. School of Life Sciences, Sambalpur University, Jyoti Vihar, Burla, Sambalpur, Odisha, India. Email address: bimaljit2019@gmail.com 


\section{Introduction}

Asthma is a globally important non-communicable disease of a major public health concern due to its significant morbidity, mortality, and clinical severity in both children and adults. ${ }^{1}$ Although prevalence, severity, and mortality vary with respect to the geographical location, psychological, and environmental factors, genetic determinants as well as sex also play a prominent role in modulating disease severity. ${ }^{2,3}$ As per the evidence, low- and middle-income countries exhibit higher mortality ratios compared to high-income countries, where the disease is most prevalent. ${ }^{4}$ More than 300 million people are affected by asthma in the world and it is expected that a further 100 million will be affected by $2025 .{ }^{5}$ Although the role of key molecular players in the progression of the disease is yet to be understood, the disease is characterized by the persistence of chronic airway inflammation, respiratory tract infection, airway wall remodeling, edema, and mucus hypersecretion, which is significantly associated with prolonged cough, chest pain or chest tightness, episodes of wheezing and shortness of breath. ${ }^{6}$

Studies on in vitro and in vivo techniques include diverse experimental approaches in cell culture and human clinical models represent the basic molecular network involving potent molecular signals and their pathophysiologic scenario instigating cellular activation, oxidative stress stimulating inflammatory milieu leading to the pathogenesis, and severity of the disease. ${ }^{7-10}$ Epidemiological evidence indicates significant involvement of multicellular populations and their activation leading to disease progression and pathogenesis. The cellular activation and severity are characterized by the release of potential biochemical and inflammatory mediators such as cytokines, chemokines, eicosanoids, growth factors, oxidative stress, neural mediators, nitric oxides, and abnormal expression of cell adhesion molecules. Accumulation of these factors promotes smooth muscle cell hyperplasia, goblet cell hyperplasia, epithelial/subepithelial shedding and fibrosis, and blood vessel dysfunction ultimately leading to airway remodeling. ${ }^{11}$ Exposure to environmental stimuli and allergens causes activation and recruitment of of a variety of cellular populations such as macrophages, dendritic cells, airway epithelial cells, neutrophils, eosinophils, and mast cells inducing cellular damage and inflammatory response in patients with asthma. ${ }^{12}$

\section{Eosinophils are in activated state in asthma}

Eosinophils are the major inflammatory cells which play a crucial role in the development of allergic and non-allergic asthma phenotypes..$^{13,14}$ The cell is a bone marrow-derived granulocyte with bilobed nucleus having characteristics of acidophilic granules and originated from the eosinophil colony, forming a unit of myeloid progenitor cells and regulated by a variety of signaling molecules like chemokines, cytokines, and adhesion molecules. The cells play an important role, particularly in the immune response against allergic inflammation and parasitic reactions. Eosinophil development in the bone marrow is stimulated by interleukin-3 (IL-3) and granulocyte macrophage colony-stimulating factor (GM-CSF), early differentiation factor and interleukin-5
(IL-5), late differentiation factor which is only active in eosinophil and basophils. ${ }^{15-17}$ Eosinophilia in patients with asthma-especially sputum and blood-are significantly associated with basement membrane inflammation of airway mucosa in comparison to the non-atopic control subjects. ${ }^{18-20}$

Plenty of evidence indicates variations in eosinophil count with respect to different corticosteroids thus regulating asthma severity. ${ }^{15,21,22}$ Airway eosinophilia is significantly associated with exacerbation and plays a predominant role in airway remodeling. Several cell adhesion receptor expressions on activated eosinophils are highly crucial in mediating eosinophil arrest in the vascular region, extravasations into the airway wall through bronchial and epithelial tissue to the airway lumen. It is evident that eosinophils in their activated state are characterized by an increase in inflammatory mediators and granular proteins in the blood, sputum samples, bronchoalveolar lavage fluid (BAL), and bronchial biopsy specimens in patients with asthma. ${ }^{23-25}$ Eosinophil infiltration has been observed to cause vasodilatation, microvascular obstruction, and disruption of epithelial cells. ${ }^{26}$

Both genetic and environmental factors containing allergens activate a variety of immune cells and epithelial cells finally leading to eosinophil activation, recruitment, and trafficking. ${ }^{27}$ Activated eosinophils are characterized by overexpression of several eosinophil surface adhesion molecules; some receptors also behave as enzymes, receptors for immunoglobulin G (IgG) immunoglobulin A (IgA), cytokines, chemokines and complement proteins which are implicated in cell adhesion, apoptosis, signal transduction, eosinophil trafficking, proliferation, activation and promotion of survival and death. ${ }^{28,29}$ The activation state of the eosinophils constitutes several activation markers that play a key role in airway remodeling, eosinophil trafficking, and extravasations. ${ }^{30}$ Although several cell surface proteins are observed to report the eosinophil activation, the role of integrins is highly crucial. Earlier evidence also indicates that integrins play a predominant role in pulmonary function and airway inflammation. General markers of eosinophil activation include clusters of differentiation 69 (CD69), CD11b, CD4, CD9, CD35, CD44, CD45RO, CD48, CD58, CD63, CD66e, CD11a, CD69, CD67, CD81, CD11C, CD18, CD16, CD32, CD64, CD23, CD89, CD54, CD123, CD125, CD62L, CD162, CD108, CD29, CD18, CD32, $\beta 2, \beta 1$, thymic stromal lymphopoietin receptor (TSLPR), neuropeptide SR, interleukin 17 receptor A (IL-17RA), IL-13Ra1, human leukocyte antigen DR isotype (HLADR), Galectin 3, platelet-derived growth factor B chain (PDGF-B), and stem cell factor (SCF) (Figure 1). It was reported that eosinophils and $\mathrm{T}$ lymphocytes are increased in the asthmatic airways with respect to non-asthmatic controls. ${ }^{31-34}$ However, the receptors are also expressed by other cells such as neutrophils, basophils, and mast cells. The only receptor specific to the eosinophils is the epidermal growth factor-like module containing mucinlike hormone-like receptor 1 (EMR1). ${ }^{35}$

\section{Molecular players leading to eosinophil activation}

Accumulation of activated eosinophils in the submucosa region is the prominent indicator of inflammation in 


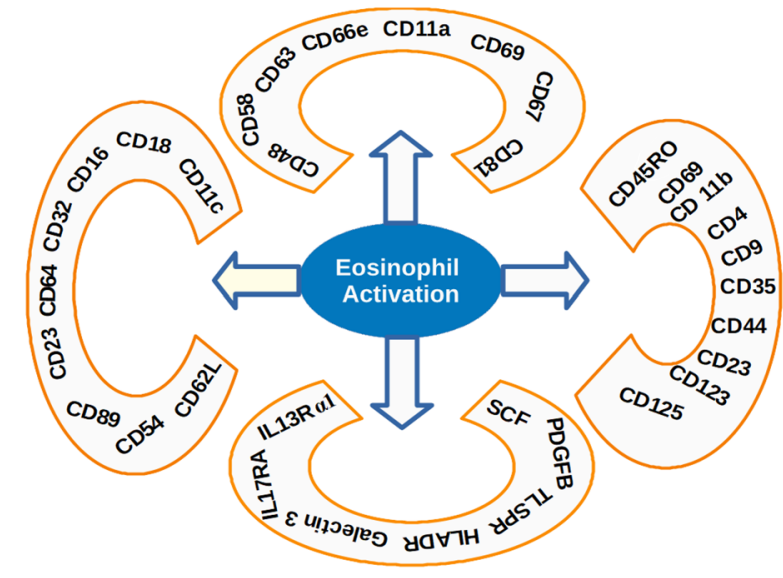

Figure 1 Upregulation of eosinophil surface adhesion molecules in asthma. The eosinophils in their activated state are characterized by overexpression of several cell adhesion receptors as shown in the figure. Instigated by several stimuli eosinophil displays the following CAMs and also releases potent toxic signaling molecules. This contributes to a concomitant increase in inflammatory mediators and granular proteins in the blood, sputum samples, BAL, and bronchial biopsy in patients with asthma, culminating in pathological manifestations.

asthma. Activated eosinophils are reported to be significantly associated with asthma severity. On activation, eosinophils release several potent toxic signaling molecules such as major basic proteins, eosinophil peroxidase, eosinophilic cationic proteins, and lipid mediators rendering tissue damage and subsequently leading to allergic manifestation. ${ }^{36}$ The role of cysteinyl leukotriene in the exacerbation of tissue eosinophilia has been previously described. An elevated level of cysteinyl leukotriene in modulating bronchoconstriction, mucus hypersecretion, tissue infiltration, vascular permeability, and inflammation has been reported by earlier studies. ${ }^{37,38}$ In addition, the role of leukotriene in inducing eosinophil activation by stimulating lung cells for the production of regulated on activation, normal T cell expressed and secreted (RANTES) has been proposed. ${ }^{39}$ Furthermore, an elevated level of leukotriene B4 (LTB4) has been reported, this is a lipid mediator with possible chemo attracting property that has been investigated in patients with asthma. The molecule is released by a variety of cell types including mast cells, macrophages, and neutrophils which mediate its action by acting on G-protein coupled receptor (GPCR) and LTB4 receptor 1 (BLT1) expressed by eosinophils. Although the role of leukotriene B4 receptor (LTB4) in human eosinophil activation, chemotaxis, and pathogenesis of asthma is poorly understood, the potent role of LTB4 in the activation of mice eosinophils has been previously described. ${ }^{40}$ The increase in cytokine content and its implications in the activation of asthma have been well studied. Several pro-inflammatory cytokines have been observed to be produced by the activated eosinophils such as interleukin 1 beta chain (IL-1 $\beta$ ), IL-6, and tumor necrosis factor- $\alpha$ (TNF- $\alpha$ ) along with chemokines including IL-8/chemokine (C-X-C motif) ligand 8 (CXCL8), growth-regulated oncogene (GRO)- $\alpha / C X C L 1$, macrophage inflammatory protein-1 $\beta$ (MIP-1 $\beta) /$ chemokine (C-C motif) ligand 4 (CCL4), membrane cofactor protein (MCP-1)/CCL2, and RANTES/CCL5. ${ }^{41,42}$ In addition to this, both TNF- $\alpha$ and interferon-gamma (IFN- $\gamma$ ) can induce the expression and release of type $1 \mathrm{~T}$ helper (Th1) and Th2 derived chemokines such as CXCL-9 and CXCL-10, possibly by activating nuclear factor kappa-light-chain-enhancer of activated $B$ cells (NF-kB), signal transducer and activator of transcription (STAT1), and STAT6. ${ }^{43}$

The response to different allergens, bacterial, fungal, and parasitic infection induces the production of cytokines such as interleukin 3 (IL-3), IL-4, IL-5, IL-13, and granulocyte-macrophage colony-stimulating factor (GM-CSF). ${ }^{44,45}$ It was also previously reported that TNF-a plays an important role in the secretion of IL-4, IL-6, and IFN- $\gamma$ from a variety of immune cells including eosinophils. Earlier evidence suggests the possible role of IL-23, a member of the IL-12 family that plays an important role in asthma severity. IL-23 is expressed by dendritic cells and macrophages in response to microbial stimuli such as peptidoglycan, lipopolysaccharides (LPS). The physiological role of IL-17A, IL-17F, and IL-23 has been elucidated in eosinophil activation in asthma and its role in inflammation. ${ }^{46,47} \mathrm{IL}-23$ can also stimulate IL-17F production by eosinophils. Synergistically, IL-23 and IL-17F activate eosinophils and produce IL-1 $\beta$ and IL-6, which in turn, in combined treatment, can induce CXCL1, CXCL8, and chemokine 14 (CCl4). ${ }^{48}$ Activation of eosinophils is associated with an intracellular signaling pathway, leading to the secretion of several cytokines transforming growth factor-beta (TGF- $\beta$ ), MIP-1a, (GM-CSF), TNF- $\alpha$, IL-1a, IL-3, IL-5, IL-6, IL-8 can induce allergic response and tissue damage. ${ }^{44}$

Both IL-1 $\beta$ and IL-6 can induce the expression of transcription factor retinoic-acid-receptor-related orphan nuclear receptor gamma (RORy), which can be further sustained by the action of IL-17A and IL-6, leading to Th17 lymphocyte differentiation. ${ }^{49,50}$ The study was further supported by the evidence that involvement of p38 mitogen-activated protein kinases (p38-MAPK) signaling pathway by which IL-23 and IL-17A can potentiate their action, whereas IL-17F possibly stimulates extracellular-signal-regulated kinase (ERK) activation. ${ }^{49}$ Both cross-talk of the pathway leads to the secretion of the diverse amount of cytokines which induce the NF-k $\beta$ pathway and mediate allergic inflammation in asthma by the activation and recruitment of various immune cells. Further study shows the possible role of IL-17F in the induction of chemokine (C-C motif) ligand 20 (CCL20) synthesis, which attracts the Th17 cells into the airway, resulting in the recruitment of additional Th17 cells and induces allergic airway inflammation. ${ }^{51}$ Intriguingly, CD4 ${ }^{+}$mediated IL-16 dependent activation of eosinophils was observed to be associated with the release of leukotriene C4 (LTC4) as well as chemokines such as RANTES, IL-6, eotaxin, and IL-4..$^{52}$ IL-4 along with IL-5, IL-6, IL-13 produced can contribute to Th2 differentiation and IgE class switching stimulating allergic inflammatory response. ${ }^{53}$

Functional interaction between CD32 and aMB2 has been observed to play an important role in eosinophil degranulation. ${ }^{54,55} \mathrm{~A}$ potential role of aMß2 integrin on eosinophil degranulation in an IgG-mediated manner has been described previously. ${ }^{56}$ An elevated level of IL-3 in serum has been positively associated with asthma 
severity. ${ }^{57,58}$ It was also reported that airway epithelial cells are IL-3 positive. IL-3 is also secreted by activated Th2 lymphocytes, mast cells, and neutrophils. An increase in IL-3 receptor expression on eosinophils suggests a possible role of IL-3 in the stimulation of eosinophil activation. ${ }^{59}$ In response to allergen challenges, the production of IL-3 induces increased translation of semaphorin A by stimulating the p90S6K/RPS6 signaling pathway. ${ }^{60}$ Earlier evidence indicates cytokines such as IL-3, GM-CSF, and IL-5 activate semaphorin A production by eosinophils. Existing evidence indicates that semaphorin A activates the TGF- $\beta 1$ signaling pathway, which induces lung fibrosis/airway remodeling in asthma. ${ }^{61}$ Earlier findings suggest activation of eosinophils by IL-3 stimulating prolonged expression of CD32 and aMB2 integrin, as well as maintaining their activation state (Figure 2). ${ }^{62}$

The role of thymic stromal lymphopoietin (TSLP), a cytokine in the induction of allergic response, in diseases such as asthma has been well studied. ${ }^{63,64}$ The protein plays an important role in atopic dermatitis, allergic rhinitis, nasal polyposis, and chronic allergic keratoconjunctivitis. ${ }^{65}$ TSLP, a member of the hematopoietic cytokine family, has been found to interact with its receptor TSLPR and interleukin 7 receptor-alpha chain (IL-7a) expressed on eosinophils and also in other cell types. ${ }^{66}$ Although, the role of TSLP in promoting the Th2 differentiation was initially attributed in a dendritic cell-mediated manner, however, subsequent results indicate its expression by various cell types which indicate that it is like eosinophils, mast cells, $B$ cells, and T cells. ${ }^{67}$ Further analysis on real-time quantitative PCR study indicates mRNA expression of TSLPR and IL-7a in eosinophils upon treatment with TNFa and IL-5 family cytokines. Stimulation of eosinophils with TSLP induces STAT3 signaling and promotes eosinophil-dependent neurotoxin (EDN) production leading ultimately to eosinophil degranulation, which can be subsequently blocked by the functional blocking antibody to TSLPR. EDNs are stored in eosinophil granules in response to a range of immobilized ligands like $\operatorname{lgA}$ and $\operatorname{lgG} .{ }^{68}$ Further study indicates a potential role of leukocyte Ig-like receptor (LER7) activation through an immunoglobulin mediated manner that can lead to EDN release from eosinophils. ${ }^{69}$ A possible role of platelet-activating factor (PAF) in aggravating the chemokinesis and chemotaxis of eosinophils has been previously reported. PAF is secreted by macrophages/monocytes, platelets, neutrophils, endothelial cells as well as eosinophils. ${ }^{70,71}$

An increased level of PAF can induce G-protein coupled receptor (GPCR) expressed by eosinophils and stimulates eosinophilotactic activity by activating the MAPK signaling pathway. In support of this notion, further studies also revealed the possible role of PAF inducing MAPK signaling in asthma. ${ }^{72-74}$ Further evidence from a mice model indicates that the administration of prostaglandin D2

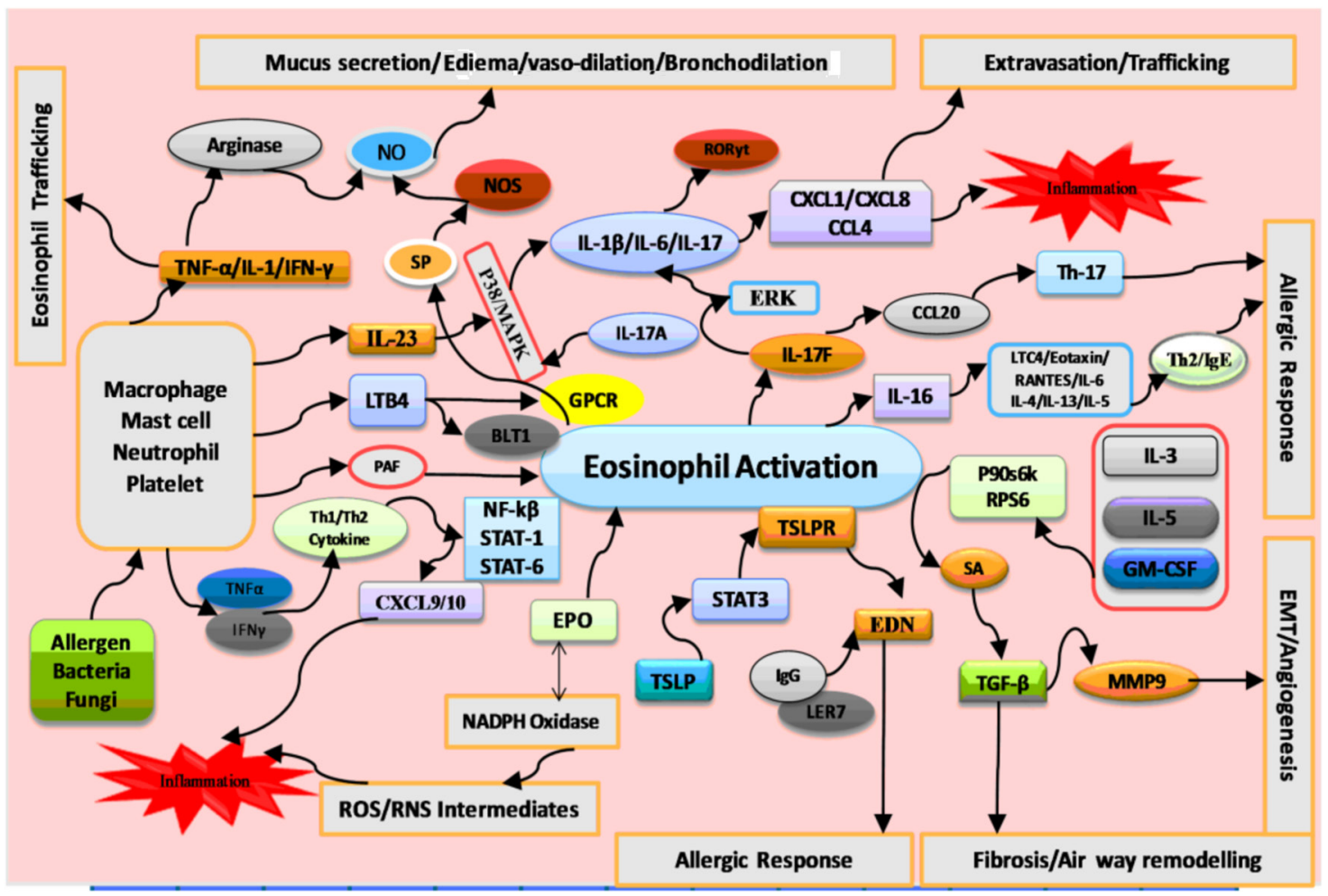

Figure 2 Signaling network modulating eosinophil activation and asthma phenotype displaying the potential role of cellular, molecular, and environmental factors inducing the complex signaling cross-talks. This ultimately leads to eosinophil activation which is characterized by overexpression of membrane-bound or secreted molecules. These molecular intermediates activate specific signaling, culminating directly or indirectly into complex abnormal phenotypes such as allergic response, airway remodeling, epithelial damage, or bronchodilation, modulating clinical severity in asthma. 
(PGD2) is significantly associated with tissue eosinophilia. ${ }^{75}$ Prostaglandin D2 (PGD2) mediated function is accomplished by its interaction with two receptors; DP1 and DP2 (D prostanoid receptor 1 and 2) expressed by $\mathrm{T}$ helper type 2 cells (Th2 cells) and eosinophils. ${ }^{76}$ Furthermore, it was established that DP2 receptor activation is highly crucial in mediating activation and eosinophilotactic activity. In vivo study revealed that prior exposure of allergens or IL-5 can significantly increase airway eosinophilia in mice induced by DP2 agonist or PGD2 by coupling with inhibitory Ga subunit (Gai), which leads to the diminished synthesis of cyclic adenosine monophosphate (CAMP) and induced accumulation of intracellular calcium. ${ }^{77}$

The proteolytic activity of matrix metalloproteinase (MMP) can lead to extracellular matrix protein degradation, which is significantly associated with tissue injury and remodeling. MMP9 causes tissue remodeling by epithelial mesenchyme transition by the release of TGF- $\beta$, profibrotic factors that can contribute to angiogenesis. Accumulating evidence indicates the role of MMP9 secretion by eosinophils when activated by IL-3, IL-5, IL-8, TNF- $a$, GM-CSF, complement $5 \mathrm{a}$, and PAF. ${ }^{78-83}$ Activation of eosinophil GPCR by PAF, endothelin-1, RANTES, eotaxin, cyteinyl leukotrienes, prostaglandins, complement component $3 \mathrm{a}(\mathrm{C} 3 \mathrm{a}), \mathrm{C} 5 \mathrm{a}$ and other stimuli can activate phospholipase $C \beta$ \{Phospholipase C- $\beta$ (PLC- $\beta$ ) $\}$, which in turn causes hydrolysis of phosphatidylinositol bisphosphate into inositol triphosphate and diacylglycerol inducing calcium accumulation and protein kinase C (PKC) activation. ${ }^{84-86}$ Furthermore, it was also reported that the combined action of IL-3 and TNF- $\alpha$ can activate eosinophils inducing activation of NF-kB and MAP kinase pathway involving ERK1/2 and p38 but not (c-Jun $\mathrm{N}$-terminal kinase) JNK pathway leading to the synthesis and release of MMP9. ${ }^{87}$ Recent studies have also shown the secretion of MMP-9 by eosinophils on activation by IL-3 and TNF- $a .^{88}$ The release of MMP-9, NF-kB activation has also been associated with the regulation of IL- 8 and expression of intracellular cell adhesion molecule 1 (ICAM-1). ${ }^{89}$ It was also reported that TNF- $\alpha$ can induce synthesis of eotaxin by activation of eosinophils and P38 MAPK signaling pathway. ${ }^{90,91}$ Earlier evidence indicates an accumulation of a large number of CXC and CC chemokines in human and pig models of allergic inflammation..$^{92-94}$ Both eosinophils and basophils possess eotaxin receptor CCR3 which plays a crucial role in inflammation and allergic response. ${ }^{95,96} \mathrm{~A}$ study on biopsy specimens in asthmatic patients also indicates the expression of eotaxin protein by eosinophils in inflammatory sites. Further study significantly revealed the potential ability of C5a, TNF-a, and IL-4 in the activation and release of eotaxin by eosinophils. ${ }^{97}$ Stimulation of eosinophil CCR3 by eotaxin induces tyrosine phosphorylation of numerous proteins such as Lyn, hematopoietic cell kinase (Hck), and Fgr leading to eosinophil chemotaxis and recruitment (Figure 2). ${ }^{98}$

A possible role of IL-5 and nitric oxide metabolites was reported and intriguingly it was observed that patients with a higher concentration of IL-5 and nitric oxide (NO) possess a higher concentration of ECP. ${ }^{99} \mathrm{NO}$ also plays a crucial role in the pathophysiology of asthma. A higher concentration of NO released by inducible nitric oxide synthase (iNOS) and endothelial nitric oxide synthase (eNOS) exerts its effect by promoting mucus secretion, vasodilation, plasma extravasation, edema, and $\mathrm{T}$ lymphocyte and eosinophil recruitment, whereas NO released by neuronal nitric oxide synthase (nNOS) induces bronchodilation by relaxing smooth muscles, possibly by non-noradrenergic, noncholinergic (NANC) nerve activation. It has been previously described that activation of a variety of cell populations such as eosinophils, epithelial cells, endothelium, muscle cells, neurons, fibroblasts, $T$ and B lymphocytes, mast cells, macrophages, and dendritic cells releases substance $\mathrm{P}$ (SP). ${ }^{100}$ The role of SP in the induction of eosinophil activation and NO synthesis has been observed in several models. ${ }^{100-102}$ In addition to SP potential role of other peptides like formyl-methionyl-leucyl-phenylalanine (FMLP) and melittin in contributing to eosinophil activation in guinea pig models has been described, where SP and melittin act presumably through non-specific peptide membrane phospholipid interactions and FMLP acts through receptor-mediated manner. ${ }^{103}$ Accumulation of cytokines such as TNF- $\alpha$, IL-1, IFN- $\gamma$, and lipopolysacharides (LPS) can induce L-arginine transport and thus activate arginase and iNOS activity leading to NO production. ${ }^{104,105} \mathrm{~A}$ high concentration of NO can stimulate metalloproteinase activity, activation of oxidative stress pathway, airway remodeling, cellular activation and recruitment, inflammatory response, airway hyperresponsiveness, and allergic stimulation. ${ }^{106}$

The expression and activation state of several integrins by eosinophils is significantly associated with the migration and adhesion of different extracellular matrix (ECM) proteins. Eosinophils express $\alpha 4 \beta 1, \alpha 6 \beta 1, \alpha L \beta 2, \alpha M \beta 2$, $\alpha \times \beta 2, \alpha D \beta 2$, and $\alpha 4 \beta 7$ integrins, where each integrin interacts with its ligand, which are the counter receptors on different cell or ECM components. ${ }^{55,107,108}$ Eosinophils via these integrins can adhere to ICAM-1, vascular cell adhesion molecule-1 (VCAM-1), laminin, periostin, fibrin/fibrinogen, vitronectin upon stimulation with different signals such as IL-5, IL-3, GM-CSF, and P-selectin. ${ }^{55,109,110}$ Results from both in vivo and in vitro models indicate eosinophil integrin expressions are highly crucial in the modulation of the inflammatory response in asthma. ${ }^{31,109,111,112}$ Different signals such as epinephrine and thrombin, express vascular endothelial growth factor (VEGF), histamine and adenosine phosphate (ADP) induce the generation of P-selectin from platelets and endothelial cells which act on P-selectin glycoprotein ligand-1 (PSGL-1) expressed by eosinophils and other leukocytes, which could lead to the activation of $\beta 1$ integrin and induce its adhesion to VCAM-1. ${ }^{113-116}$ Although P-selectin has the potential to induce eosinophil $\beta 1$ integrin activation, there is, however, considerable discrepancy about the exact mechanism of the signaling pathway involved. The influence of different leukotrienes such as C4, D4, E4 in activation of eosinophils was also reported in asthma. ${ }^{37,117,118}$

Oxidative stress has proven to be an intrinsic modulator in triggering the pathological complexity of asthma characterized by oxidant-antioxidant imbalance. ${ }^{119}$ Elevation of endogenous and exogenous reactive oxygen species (ROS) and nitrogen species (RNS), decreased level of cellular antioxidants, inflammatory cell infiltration, metabolic disorders, increased level of allergen-induced environmental peroxidants, genetic and epigenetic alterations, and poor lung functions are significantly associated with oxidative stress. It was also previously described that asthma 
severity and airway inflammations are significantly affected by endogenous and exogenous ROS and RNS. Oxidative stress plays a crucial role in aggravating the inflammation and pathogenesis of both mild and symptomatic cases. Exogenous sources of ROS include cigarette smoke, hyperoxia, heavy metal poisoning, UV light, ozone, ionizing radiation, pollutants, organic solvents, and chemotherapeutic agents, whereas the source of endogenous substances includes enzyme activities and the activation of immune and non-immune cells. Augmented production of ROS was also previously reported in both children and adults, with distinct severity. ${ }^{120}$ Tremendous generation of ROS such as superoxide radicals, hydrogen peroxide, hydroxyl radicals, singlet oxygen, hypochlorous acid, peroxyl, alkoxyl, and hydroperoxyl free radicals, like RNS such as nitric oxide (NO), peroxynitrite, and nitrite, modulate airway inflammation and asthma severity. ${ }^{121}$ Activation of eosinophils, macrophages, neutrophils, and monocytes is associated with the generation of superoxides. Heterocellular activation, allergen exposure, and challenge lead to a diverse amount of production of chemokines, lipid mediators, cigarette smoke and potent air pollutants such as ozone and diesel exhaust particles that can promote ROS production. ${ }^{122,123}$ High blood eosinophil counts are associated with moderate to severe asthma in comparison to the high blood neutrophil count, which is associated with only moderate but not severe asthma phenotype. ${ }^{124}$ Activation of cell organelles such as mitochondria, endoplasmic reticulum, peroxisome, allergen exposure, activates of xanthine oxidase, P450 monooxygenase, cyclooxygenase, lipoxygenase, indoleamine dioxygenase, monoamine oxidases, dehydrogenases, dioxygenases activity leads to the generation of free radicals. Earlier evidence also indicates an elevated level of ROS and RNS in patients with asthma. ${ }^{125,150}$ Several markers of oxidative stress have been reported in the exhaled airway of patients with asthma. An excess concentration of ROS has been observed to be associated with airway hyperresponsiveness, vascular permeability, production of chemoattractants, and lipid peroxidation. ${ }^{125}$ The interaction of ROS with biomolecules such as proteins to form carbonyl; this subsequently reacts with nitrogen species and tyrosine to form nitrotyrosine. This was also previous evidence that patients with asthma are characterized by increased activity of eosinophil peroxidase (EPO) and myeloperoxidase (MPO) in eosinophils as well as neutrophils. ${ }^{126}$ The product of these enzymes such as 3-bromotyrosine and chlorotyrosine is reported to increase in asthmatic subjects compared to the controls. ${ }^{127,128}$ Increased levels of NO and superoxide can induce epithelial cell shedding leading to neuropeptide release and contribute to bronchoconstriction.

Multiple lines of evidence also indicate the potential ability of eosinophils/neutrophils contributing ROS production in the lung airways in comparison to healthy controls. It was previously described that eosinophils isolated from asthmatic patients are characterized by the production of more hydrogen peroxide as well as ROS in comparison to healthy controls. The increased concentration of ROS can overwhelm the endogenous antioxidant status and leads to a loss in beta-adrenergic function, mucin secretion, acetylcholine-mediated muscle sensitization and contraction, activation of mitogen-activated protein kinase in tracheal myocytes. Activated neutrophils, macrophages, and monocytes have the ability to generate superoxide and hydrogen peroxides. Eosinophils have the tremendous potential to release these free radicals in comparison to the neutrophils, due to high EPO activity than MPO activity in neutrophils. ${ }^{129}$

The effect of CC chemokine eotaxin has been observed to be associated with eosinophil activation and the production of ROS by eosinophils. ${ }^{130}$ The possible role of ROS in stimulating expression of soluble intracellular adhesion molecule 1 (ICAM-1) by eosinophils was also previously reported. A previous study has also demonstrated the possible role of eotaxin and RANTES in activation of CCR3 in a GPCR-mediated manner involving the activation of phosphatidylinositol-3-kinase and tyrosine kinase. ${ }^{95}$ The influence of cytokines on the eosinophil NADPH activity was studied in vitro. ${ }^{131}$ It was evident that IFN- $\gamma$ and TNF-a can induce NADPH activity and gp91-phox gene in human myeloid leukemia 60 (HL-60) clone 15 cells which induce eosinophil differentiation and release of reactive oxygen intermediates in the chronic inflammatory condition in asthmatic patients. ${ }^{132}$ The treatment of chemokines such as CCL11, CCL24, CCL26 can stimulate isolated eosinophils to produce superoxides. The concentration-dependent degranulation of eosinophil peroxidase (EPO) and calcium ion influx was also observed. Potentiation of the response was observed maximally in the case of CCL11 and CCL24 even in Phorbol 12-myristate 13-acetate (PMA) stimulated conditions. Pre-treatment of cells with antiCCR3 antibody significantly inhibits superoxide generation, indicating the possible role of CCR3 as a target for eotaxins. ${ }^{133}$ Upregulation of CCR3 by butyric acid (BA) and IL-5 as observed in HL-60 clone 15 cells indicates a cooperative action of chemokines for the effective inflammatory response in asthmatic patients. ${ }^{134,135}$ Further study also revealed the potential effect of IL-5 and PMA in eosinophil priming and the subsequent generation of oxygen-free radicals possibly by activation of the MEK-ERK1/2 pathway..$^{136}$ A subsequent study reported that peripheral blood eosinophils are characterized by enhanced production of ROS, chemotaxis, and a diminished level of apoptosis during allergen-induced late-phase airway inflammation. ${ }^{137}$

Increased activity of NADPH oxidase in eosinophils was observed during infection stages which release a massive quantity of superoxides. ${ }^{138}$ Several potent signaling molecules are associated with eosinophil NADPH oxidase activation, as epidemiological evidence in both human and guinea pig model indicates phospholipase $C$ (PLC) and phospholipase D (PLD), activation MAP kinase/tyrosine kinase plays a crucial role in inducing eosinophil NADPH activity. ${ }^{139,140}$ Activation of PLD is associated with phosphatidylcholine (PC) and phosphatidic acid (PA). PA observed to phosphorylate NADPH oxidase by activation of protein kinases, in addition to this $\mathrm{C} 5 \mathrm{a}$ also plays a crucial role in PLD activation. It was earlier evidence that the potential ability of arachidonic acid (AA) stimulates $\mathrm{H}_{2} \mathrm{O}_{2}$ generation in a concentration-dependent manner in guinea pig eosinophils. Activation of PLA2 cleaves membrane lipids gives rise to AA production which induces rac p21 translocation stimulating NADPH activation. In addition to this, AA also activates PKC, MAP kinase and increases intracellular $\mathrm{Ca}^{2+}$ concentration. Activation of MAP kinases such as ERK1/2, JNK46/54, and p38 kinase are implicated in NADPH oxidase 
activation. ${ }^{141,142}$ Further study revealed the possible role of CLC3, a chloride channel and $\mathrm{H}^{+} / \mathrm{Cl}^{-}$antiporter in activation of eosinophil NADPH oxidase and induction of oxidative burst leading to eosinophil activation and migration. ${ }^{143}$ Since sustained activation of NADPH oxidase is solely dependent on the costimulation of the ion transporter which maintains the charge balance generated by $\mathrm{O}_{2}^{-}$production from NADPH oxidase. It was also proposed that PKC plays an important role in the phosphorylation of CLC3 inducing eosinophil degranulation, superoxide generation by stimulating NADPH oxidase activity. ${ }^{144}$ A potent role of IL-33 has been observed to activate the CCR3 expressed by eosinophils and induces NADPH oxidase 2 (NOX2) expression in eosinophils. ${ }^{145}$

The action of NADPH oxidase generates superoxide in activated eosinophils which is subsequently converted into $\mathrm{H}_{2} \mathrm{O}_{2}$ which is a potent substrate candidate for EPO and converted into hypobromous acid, which in turn reacts with amine and tyrosine amino acid to give rise to 3-bromotyrosine. It was also previously evident that activated eosinophils have 3-10 times superoxide producing ability as compared to the neutrophils. ${ }^{146}$ Plenty of evidence indicates that EPO activity is significantly associated with asthma severity and tissue inflammation and is also a predominant factor for the production of hypobromous acid in the airways. ${ }^{147,148}$ In response to the allergen challenge, there is a 10 -fold increase in the level of 3-bromotyrosine in the proteins isolated from BAL and sputum asthmatic patients in comparison to non-asthmatic subjects. ${ }^{128,147}$ In addition to the oxide generation ability, eosinophils have a prodigious ability to produce RNS on reaction with NO derived intermediates. ${ }^{150,151}$ RNS generation by eosinophils in asthmatic patients mostly contributed by alterations in NO metabolism. Activation of NOs by different cytokines such as IL-13, IL-14, IFN- $\gamma$, and TNF- $\alpha$ leads to the production of NO from L-arginine enzymatically. The NO generated can combine with superoxide to form peroxynitrite, which in turn combines with $\mathrm{CO}_{2}$ to form peroxycarboxynitrite. EPO activation can use halides and pseudohalides to form a more potent form of oxidants. ${ }^{152}$ Parallel gas chromatography and mass spectrometry results significantly revealed that there is a 10 -fold increase in 3-nitrotyrosine in proteins recovered from BAL from asthmatic subjects in comparison to non-asthmatic subjects. ${ }^{127}$ Nitrosothiol and nitrotyrosine production can lead to protein inactivation. It has also been observed that an elevated level of nitrotyrosine is found in the airways of patients during an asthma attack. ${ }^{153,154}$ Eosinophils use EPO, which plays a crucial role in the oxidative modification of proteins.

Eosinophilia asthma phenotypes are the most prognostic biomarkers and indicators to assess the disease severity, although the distinct phenotypes are associated with airway microbiology. High blood eosinophilia and its association with disease exacerbation were explained by a previous study. ${ }^{19}$ Eosinophils have an intrinsic ability to rapidly release a vast number of tissue mediators such as growth factors, cytokines, chemokines, and eosinophilderived granules. Activation of eosinophils, expression and activation state of cell adhesion molecule (CAM), interaction of eosinophils with other cells such as platelets and neutrophils instigated by several confounding factors, is significantly associated with airway hyperresponsiveness, airway remodeling, epithelial cell damage, vascular cell adhesion molecule expression culminating in an inflammatory response. Eosinophil recruitment and priming in a chemoattractant-mediated mechanism involves transmigration, extravasations, possibly by tethering and rolling over the vascular endothelium play an important role in inducing an inflammatory response. PGD2 derived from the mast cell activation induces chemotaxis in eosinophils in a CR2H2-mediated manner and stimulates oxidative burst in eosinophils. CR2H2 antagonists have been observed to be associated with the suppression of eosinophil chemotaxis and oxidative burst. ${ }^{155,156}$ Activated eosinophils also express vascular endothelial growth factor (VEGF) in response to the GM-CSF and IL-5. VEGF is reported to play a crucial role in mediating endothelial cell-specific response and vascular leakage contributing to tissue edema formation at the site of allergic inflammation. ${ }^{157}$

\section{Eosinophils in modulating epithelial injury}

Impairment in epithelial function was observed in asthma, presumably by disruption of epithelial tight junctions, accompanied by tissue injury and aberrant repair orchestrated inflammatory response in asthma. Although epithelial cells are reported to recognize and engulf apoptotic eosinophils, activated eosinophils release potent cytotoxic granules, EPO, Mannan-binding protein (MBP), EDN, ROS, RNS, TGF- $\beta$, IL-13, IL-4, IL-8, IL-11, ECP, and other chemokines, which leads to epithelium damage. ${ }^{158} \mathrm{IL}-13$ has been observed to activate STAT- 6 signaling and stimulates airway hyperresponsiveness and mucus secretion in epithelial cells. ${ }^{159-161}$ Epithelial injury during this stress condition is associated with the activation of NF-kB, AP-1, growth factors, and chemokines which aggravates the inflammation process. Production of TGF- $\beta$, TGF- $\alpha$, PAF, IL-13, IL-5, IL-17, IL-10, leukotrienes, thromboxanes, prostaglandins, and other cytokines by activated epithelial cells and eosinophils coupled with stimulation of myofibroblasts due to accumulation of type-III collagen. In response to allergen and LPS, it induces TL4 signaling epithelial cells ultimately leading to the production of TSLP, IL-33, and IL-25 to regulate the adaptive immune response. CCL2 and CCL20 produced by activated epithelial cells also activate dendritic cells, which in turn regulate allergen processing and the presentation to T lymphocytes. Eosinophil MBP and EPO with $\mathrm{H}_{2} \mathrm{O}_{2}$ and halide reported activating basophils and mast cells which produce leukotrienes and histamine causing epithelial injury. The toxic cationic granules, viral and bacterial infection also cause desquamation of bronchial epithelial cells inducing bronchial hyperreactivity and loss of epithelium-derived relaxing factors. Intratracheal instillation of eosinophil in lungs increases the concentration of chemokines such as MCP-1/CCL2, which are the potent chemoattractant for macrophages and lymphocytes producing an inflammatory response. The prospective role of eosinophils in inducing the epithelial-mesenchymal transition (EMT), and release of collagen, fibroblast growth factors (FGF), TGF-B1 was elucidated previously. ${ }^{162,163}$ EMT, a molecular reprogramming process, involves increased migration of mesenchymal cells to subepithelial connective tissues and is characterized by increased secretion of extracellular 
matrix proteins (ECM) leading to bronchial wall fibrosis in injured sites. ${ }^{164,165}$ In vitro evidence also indicates secretion of fibroproliferative and fibrogenic growth factors including FGF-2, insulin-like growth factors 1 (IGF-1), PDGF, ET-1, and TGF- $\beta$, which can induce collagen gene expression. ${ }^{166-169}$ It was observed that eosinophil and epithelial cell interaction causes the release of TGF- $\beta 1$ by bronchial epithelial cells, which activates JNK/Smad3 pathway causing EMT of airway epithelial cells. ${ }^{170}$ EMT plays a significant role in airway remodeling. The secretion of IL-37 by epithelial cells as well as macrophages and neutrophils induced by allergen exposure, bacterial and viral infections, which mediates eosinophil recruitment and activation upon interaction with $\mathrm{N}$-formyl peptide receptor 2 (FPR2) and P2X7R and induces cysteinyl leukotrienes (CysLT) by activating p38MAPK and nf-kB signaling pathway. ${ }^{171,172}$ Epidemiological evidence revealed the expression of macrophage inflammatory protein 1-a (MIP-1a), IL-8, epidermal growth factor receptor (EGFR), and CD44 expression by epithelial cells; this indicates a potential marker of epithelial injury. In vitro results from airway epithelial cell indicate epithelium dysfunction is associated with increased secretion of cytokines, chemokines, eicosanoids such as prostaglandin $\mathrm{E}_{2}$, 15-hydroxyeicosatetraenoic acid, IL-6, which induces an inflammatory response. ${ }^{173,174}$

\section{Drug approach to eosinophilic asthma}

The complex clinicopathological features of asthma enable it to behave as a heterogeneous disease. Until recently, the current scenario indicated that the basic pathophysiological picture of the phenotype is characterized with exacerbated severity. Understanding the complexity of the phenotype is highly crucial in order to improve the patient outcome and better therapeutic efficacy. Although tissue-specific eosinophil activation plays an important role, associated organ dysfunction is less frequent in patients with asthma. Inhibition of eosinophil activation and priming could diminish the tissue eosinophilia and protect from end-organ damage. Corticosteroid therapy has been observed to be effective in controlling the symptoms of many patients when taken with or without long-acting beta-agonists. It was also observed that the intake of oral steroids with high dose intramuscular injection triamcinolone is associated with a decrease in sputum eosinophilia. A previous study has also demonstrated the dose-response relationship between inhaled corticosteroid therapy (ICS) and blood eosinophils, which indicates that ICS at a dose of $800 \mu \mathrm{g} /$ day could significantly inhibit the tissue eosinophilia and eosinophil cationic protein (ECP). ${ }^{175}$ The study also showed that inverse agonist propanolol produced no significant effect when given with low dose ICS, whereas with higher dose ICS there is a significant improvement in airway responsiveness and inflammation was observed. ${ }^{175}$ Although long-term corticosteroid therapy could lead to corticosteroid resistance, previous investigations have elucidated that it is highly desirable to use corticosteroid therapy along with bronchodilators to boost a better response in patients with asthma. ${ }^{176-178}$ The role of leukotrienes in modulating the immune function and bronchial smooth muscle constriction was elucidated previously. ${ }^{38,39,86,117}$ The compounds have 5000 times more potent bronchoconstrictors such as histamine, prostanoids, and platelet-activating factors. Potent CysLT, receptor antagonists such as montelukast, zafirlukast, and pranlukast are clinically approved and conventionally used in asthma. Although the exact incidence of eosinophilic asthma is yet to be understood, severe asthma groups that account for $5-10 \%$ of the asthmatic population exhibit sputum eosinophilia ( $\geq 2 \%$ ), whereas $32-40 \%$ of the population exhibit a blood count $(\geq 300$ cells $/ \mu \mathrm{L}) .{ }^{178} \mathrm{~A}$ double-blind randomized placebo-controlled trial revealed that treatment with montelukast significantly decreased the serum concentration of IL-4, soluble intercellular adhesion molecule-1 (sICAM-1), ECP and peripheral blood eosinophil count indicating potential clinical benefits with asthmatic patients from bronchial hyperresponsiveness. ${ }^{179}$ Another double-blind placebo-controlled trial also indicated the inhibitory action of zafirlukast on inhaled leukotriene D4 in both asthmatic patients and normal subjects. Significant attenuation was observed in terms of early and late phase response to inhaled antigen and a decrease in bronchial hyperresponsiveness to histamine on treatment with zafirlukast. ${ }^{180}$ The potential inhibitory activity of salmeterol and zileuton on LTB4, LTA4, 5-lipoxygenase activity and its associated products makes it an ideal agent to act as a potent leukotriene inhibitor. ${ }^{181}$ Existing evidence indicates an inhibitory effect of Levalbuterol on airway smooth muscle cell proliferation and cell growth, possibly by activating the CAMP/PKA pathway and inhibiting phosphoinositide 3-kinase (PI-3 kinase), NF-kB and retinoblastoma (Rb) protein expression. ${ }^{182}$ Despite increasing the dose of inhaled corticosteroids, the addition of long-acting $\beta$-agonist salmeterol offers a better therapeutic response in asthmatic control. ${ }^{212}$ Bronchodilators such as $\beta$-agonist and anticholinergic agents have been a good choice in patients with asthma and chronic obstructive pulmonary disease (COPD); however, the administration of $\beta$-agonist has been associated with side effects including the risk of cardiovascular complicacy, arrhythmias, hypoxemia, tachycardia, palpitations, and inflammatory response. Conversely, regarding this context, anticholinergic agents have shown limited toxicity and longer duration of bronchodilator. ${ }^{213}$ Owing to the specificity and potency, human-based monoclonal antibodies have become the intriguing target, showing maximal clinical efficacy with limited toxicity. Existing evidence indicates that the administration of mepolizumab neutralizes IL-5 and significantly reduces the eosinophil count, activation, extracellular matrix protein deposition, and eosinophilic-induced inflammation (Table 1). ${ }^{214} \mathrm{~A}$ reduction in eosinophil activation markers such as ECP and EDN, with a concomitant decrease in peripheral blood eosinophilia by benralizumab, an anti-IL-5aR mediates its action by antibody-dependent cell-mediated cytotoxicity. ${ }^{215}$ Phase III clinical trials have also demonstrated the role of benralizumab in significant ameliorating effect and improvement in lung function. ${ }^{216}$ Furthermore, a study on reslizumab significantly revealed potential clinical benefits in asthmatic patients from nasal polyps. A phase II clinical study revealed that $3 \mathrm{mg} / \mathrm{kg}$ body weight of reslizumab is biologically active and significantly reduced the sputum eosinophil count. ${ }^{223}$ However, until recently, there has been a limited study in the context of the possible role of reslizumab in controlling eosinophil function. IL-4 plays a crucial role in the initiation of allergic 


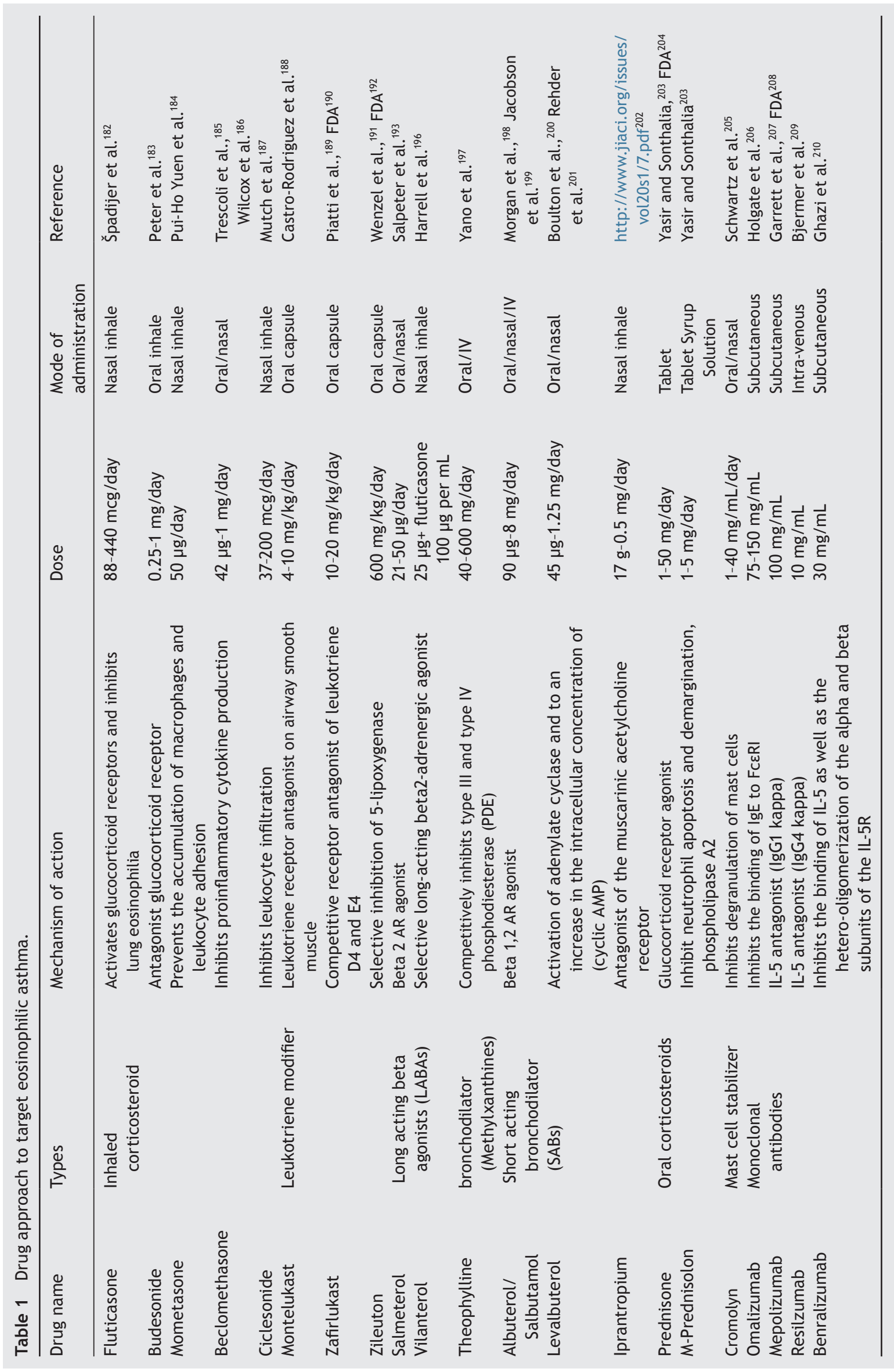


airway response and humoral response, whereas IL-13 was observed to play a potent role in the induction of allergic manifestations such as AHR, allergic inflammation, mucus production, sub-epithelial fibrosis, and airway smooth muscle alterations. ${ }^{224}$ It is interesting to note that administration with anti-IL-13 and anti-IL-4a therapy (tralokinumab, lebrikizumab, and dupilumab) although it has shown a considerable protective effect and improvement in lung function, there is a lack of significant protection in patients with asthma in terms of clinical response, indicating the need for a further massive investigation. ${ }^{217}$ In addition to antibody therapy, the possible ameliorating effect of cromolyn and its derivative in asthma has been elucidated previously. ${ }^{218,219}$ The compound has potent anti-inflammatory properties, and cytokine inhibitory activity, antihistamine activity, and a mast cell stabilizer. ${ }^{220-222}$

\section{Conclusions}

This review has described the role and behavior of eosinophils in the modulation of clinical complicacy and pathogenesis in patients with asthma. Cellular, molecular, and environmental agents could instigate the eosinophils, culminating in a more complex, comprehensive, hyperreactive phenotype in terms of morphology and biochemical complexity. Coordinated action and complex cross-talk of signaling molecules, tissue factors, cytokines, interleukins, NO, ROS, and signaling intermediates lead to altered physiology. Blood eosinophil levels represent prominent indicators of severity and act as specific biomarkers for assessing asthma severity. Eosinophil activation is associated with a myriad of signaling networks inducing a more complex heterogeneous phenotype. Tissue and blood eosinophilia could contribute to inflammation and associated infections. Assessing the exact status of eosinophils in an individual with the asthma phenotype is highly crucial for the identification of symptomatic to asymptomatic and moderate to severe phenotype. Eosinophilic inflammation represents the common pathophysiological complication, providing the rationale for the use of the potential therapeutic molecules beyond asthma. Understanding the mechanistic underpinnings at both intracellular and extracellular levels governing the eosinophil function is highly crucial. More recently, drug development has focused on blocking eosinophil recruitment into organs and impairing their survival and activation. Identification of accurate sub-phenotype with other associated eosinophilic and non-eosinophilic diseases could be an ideal strategy for a better diagnostic and therapeutic intervention. More recently, drug development has focused on blocking eosinophil recruitment into organs and impairing their survival and activation. Clinical trials with first-generation eosinophil-targeted therapeutic agents are now underway and appear to be particularly promising. Corticosteroid therapy is limited due to its toxicity and variable degree.

\section{References}

1. Eder W, Ege MJ, von Mutius E. The asthma epidemic. N Engl J Med. 2006;355(21):2226-2235. https://doi.org/10.1056/ NEJMra054308
2. Antó JM, Sunyer J, Basagana X, Garcia-Esteban R, Cerveri I, De Marco R, Heinrich J, Janson C, Jarvis D, et al. Risk factors of new-onset asthma in adults: a population-based international cohort study. Allergy. 2010;65(8):1021-1030. https:// doi.org/10.1111/j.1398-9995.2009.02301.x

3. Mukherjee $A B$, Zhang $Z$. Allergic asthma: influence of genetic and environmental factors. J Biol Chem. 2011;286(38):3288332889. https://doi.org/10.1074/jbc.R110.197046

4. Tamura N, Agrawal DK, Suliaman FA, Townley RG. Effects of platelet activating factor on the chemotaxis of normodense eosinophils from normal subjects. Biochem Biophys Res Commun. 1987;142(3):638-644. https://doi. org/10.1016/0006-291X(87)91462-8

5. Global Asthma Network. The global asthma report 2018. 2018. http://globalasthmareport.org/Global\%20Asthma\%20 Report\%202018.pdf (accessed 8 October 2018)).

6. Ordoñez $\mathrm{CL}$, Khashayar R, Wong $\mathrm{HH}$, Ferrando RO, Wu R, Hyde DM et al. Mild and moderate asthma is associated with airway goblet cell hyperplasia and abnormalities in mucin gene expression. Am J Respir Crit Care Med. 2001;163(2):517523. https://doi.org/10.1164/ajrccm.163.2.2004039

7. Holgate ST, Arshad HS, Roberts GC, Howarth PH, Thurner P, Davies DE. A new look at the pathogenesis of asthma. Clin Sci (Lond). 2009;118(7):439-450. https://doi.org/10.1042/ CS20090474

8. Ulfman LH, Joosten DP, van Aalst CW, Lammers JW, van de Graaf EA, Koenderman L et al. Platelets promote eosinophil adhesion of patients with asthma to endothelium under flow conditions. Am J Respir Cell Mol Biol. 2003;28(4):512-519. https://doi.org/10.1165/rcmb.4806

9. Monteseirin J. Neutrophils and asthma. J Investig Allergol Clin Immunol. 2009;19(5):340-354.

10. Virchow Jr. JC, Kroegel C, Walker C, Matthys H. Inflammatory determinants of asthma severity: mediator and cellular changes in bronchoalveolar lavage fluid of patients with severe asthma. J Allergy Clin Immunol. 1996;98(5):S27--S40. https://doi.org/10.1016/S0091-6749(96)70014-3

11. Durrani SR, Viswanathan RK, Busse WW. What effect does asthma treatment have on airway remodeling? Current perspectives. J Allergy Clin Immunol. 2011;128(3):439-448. https://doi.org/10.1016/j.jaci.2011.06.002

12. Lambrecht BN, Hammad H. The immunology of asthma. Nat Immunol. 2014;16(1):45-56. https://doi.org/10.1038/ni.3049

13. Walker C, Kaegi MK, Braun P, Blaser K. Activated T cells and eosinophilia in bronchoalveolar lavages from subjects with asthma correlated with disease severity. J Allergy Clin Immunol. 1991;88(6):935-942. https://doi.org/10.1016/0091-6749(91)90251-I

14. Smith SG, Chen R, Kjarsgaard M, Huang C, Oliveria JP, O'Byrne PM, et al. Increased numbers of activated group 2 innate lymphoid cells in the airways of patients with severe asthma and persistent airway eosinophilia. J Allergy Clin Immunol. 2016;137(1):75-86. https://doi.org/10.1016/j. jaci.2015.05.037

15. Tomassini M, Tsicopoulos A, Tai PC, Gruart V, Tonnel AB, Prin L, et al. Release of granule proteins by eosinophils from allergic and nonallergic patients with eosinophilia on immunoglobulindependent activation. J Allergy Clin Immunol. 1991;88(3): 365-375. https://doi.org/10.1016/0091-6749(91)90099-A

16. Gauvreau GM, Ellis AK, Denburg JA. Haemopoietic processes in allergic disease: eosinophil/basophil development. Clin Exp Allergy. 2009;39(9):1297-1306. https://doi. org/10.1111/j.1365-2222.2009.03325.x

17. Kita H. Eosinophils: multifaceted biological properties and roles in health and disease. Immunol Rev. 2011;242(1):161177. https://doi.org/10.1111/j.1600-065X.2011.01026.x

18. Brusselle GG, Maes T, Bracke KR. Eosinophils in the spotlight: eosinophilic airway inflammation in nonallergic asthma. Nat Med. 2013;19(8):977-979. https://doi.org/10.1038/nm.3300 
19. Price DB, Rigazio A, Campbell JD, Bleecker ER, Corrigan CJ, Thomas $M$, et al. Blood eosinophil count and prospective annual asthma disease burden: a UK cohort study. Lancet Respir Med. 2015;3(11):849-858. https://doi.org/10.1016/ S2213-2600(15)00367-7

20. Froidure A, Mouthuy J, Durham SR, Chanez P, Sibille $Y$, Pilette C. Asthma phenotypes and IgE responses. Eur Respir J. 2015;47(1):304-319. https://doi.org/10.1183/ 13993003.01824-2014

21. Nair P, Pizzichini MM, Kjarsgaard M, Inman MD, Efthimiadis A, Pizzichini E, et al. Mepolizumab for prednisone-dependent asthma with sputum eosinophilia. N Engl J Med. 2009;360(10):985-993. https://doi.org/10.1056/ NEJMoa0805435

22. Pavord ID. Eosinophilic phenotypes of airway disease. Ann Am Thorac Soc. 2013;10(Supplement):S143-S149. https://doi. org/10.1513/AnnalsATS.201306-168AW

23. Tibério IF, Turco GM, Leick-Maldonado EA, Sakae RS, Paiva SO, Do Patrocínio M, et al. Effects of neurokinin depletion on airway inflammation induced by chronic antigen exposure. Am J Respir Crit Care Med. 1997;155(5):1739-1747. https:// doi.org/10.1164/ajrccm.155.5.9154886

24. Miranda C, Busacker A, Balzar S, Trudeau J, Wenzel SE. Distinguishing severe asthma phenotypes: role of age at onset and eosinophilic inflammation. J Allergy Clin Immunol. 2004;113(1):101-108. https://doi.org/10.1016/j. jaci.2003.10.041

25. Possa SS, Charafeddine HT, Righetti RF, da Silva PA, Almeida-Reis R, Saraiva-Romanholo BM, et al. Rho-kinase inhibition attenuates airway responsiveness, inflammation, matrix remodeling, and oxidative stress activation induced by chronic inflammation. Am J Physiol Cell Mol Physiol. 2012;303(11):L939-L952. https://doi.org/10.1152/ ajplung.00034.2012

26. Kay $A B$. The role of eosinophils in the pathogenesis of asthma. Trends Mol Med. 2005;11(4):148-152. https://doi. org/10.1016/j.molmed.2005.02.002

27. Wardlaw AJ. Molecular basis for selective eosinophil trafficking in asthma: a multistep paradigm. J Allergy Clin Immunol. 1999;104(5):917-926. https://doi.org/10.1016/ S0091-6749(99)70069-2

28. Van der Bruggen T, Koenderman L. Signal transduction in eosinophils. Clin Exp Allergy. 1996;26(8):880-891. https:// doi.org/10.1111/j.1365-2222.1996.tb00622.x; https://doi. org/10.1046/j.1365-2222.1996.d01-391.x

29. Johansson MW. Activation states of blood eosinophils in asthma. Clin Exp Allergy. 2014;44(4):482-498. https://doi. org/10.1111/cea.12292

30. Luijk B, Lindemans CA, Kanters D, van der Heijde R, Bertics P, Lammers JW, et al. Gradual increase in priming of human eosinophils during extravasation from peripheral blood to the airways in response to allergen challenge. J Allergy Clin Immunol. 2005;115(5):997-1003. https://doi.org/10.1016/j. jaci.2005.02.002

31. Johansson MW, Kelly EAB, Busse WW, Jarjour NN, Mosher DF. Up-regulation and activation of eosinophil integrins in blood and airway after segmental lung antigen challenge. J Immunol. 2008;180(11):7622-7635. https://doi.org/10.4049/ jimmunol.180.11.7622

32. Johansson MW. Eosinophil activation status in separate compartments and association with asthma. Front Med. 2017;4:75. https://doi.org/10.3389/fmed.2017.00075

33. Rosenberg HF, Dyer KD, Foster PS. Eosinophils: changing perspectives in health and disease. Nat Rev Immunol. 2013;13(1):9-22. https://doi.org/10.1038/nri3341

34. Thomas A, Busse WW. The evolving role of eosinophils in asthma. In: Lee JJ, Rosenberg HF, editors. Eosinophils in health and disease. Amsterdam:
Elsevier; 2013. p. 431-536. https://doi.org/10.1016/ B978-0-12-394385-9.00013-4

35. Hamann J, Koning N, Pouwels W, Ulfman LH, van Eijk M, Stacey $M$, et al. EMR1, the human homolog of $F 4 / 80$, is an eosinophil-specific receptor. Eur J Immunol. 2007;37(10):27972802. https://doi.org/10.1002/eji.200737553

36. Giembycz MA, Lindsay MA. Pharmacology of the eosinophil. Pharmacol Rev. 1999;51(2):213-340.

37. Saito H, Morikawa H, Howie K, Crawford L, Baatjes AJ, Denburg $E$, et al. Effects of a cysteinyl leukotriene receptor antagonist on eosinophil recruitment in experimental allergic rhinitis. Immunology. 2004;113(2):246-252. https://doi. org/10.1111/j.1365-2567.2004.01944.X

38. Hallstrand TS, Henderson Jr WR. An update on the role of leukotrienes in asthma. Curr Opin Allergy Clin Immunol. 2010;10(1):60-66. https://doi.org/10.1097/ $\mathrm{ACl} .0 \mathrm{~b} 013 \mathrm{e} 32833489 \mathrm{c} 3$

39. Kawano T, Matsuse H, Kondo Y, Machida I, Saeki S, Tomari S, et al. Cysteinyl leukotrienes induce nuclear factor $\mathrm{kb}$ activation and rantes production in a murine model of asthma. J Allergy Clin Immunol. 2003;112(2):369-374. https://doi. org/10.1067/mai.2003.1636

40. Spada CS, Nieves AL, Krauss A-P, Woodward DF. Effects of leukotrienes B4 (LTB4) and D4 (LTD4) on motility of isolated normodense human eosinophils and neutrophils. Adv Exp Med Bio. 1997;400:699-706.

41. Chung KF, Barnes PJ. Cytokines in asthma. Thorax. 1999;54(9):825-857. https://doi.org/10.1136/thx.54.9.825

42. Lacy P, Moqbel R. Eosinophil cytokines. Chem Immunol Allergy. 2000;76:134-155. https://doi.org/10.1159/000058782

43. Liu LY, Bates ME, Jarjour NN, Busse WW, Bertics PJ, Kelly EAB. Generation of Th1 and Th2 chemokines by human eosinophils: evidence for a critical role of TNF-a. J Immunol. 2007;179(7):4840-4848. https://doi.org/10.4049/ jimmunol.179.7.4840

44. Moqbel R, Levi-Schaffer F, Kay AB. Cytokine generation by eosinophils. J Allergy Clin Immunol. 1994;94(6):1183-1188. https://doi.org/10.1016/0091-6749(94)90330-1

45. Esnault S, Kelly EA. Essential mechanisms of differential activation of eosinophils by IL-3 compared to GM-CSF and IL-5. Crit Rev Immunol. 2016;36(5):429-444. https://doi. org/10.1615/CritRevlmmunol.2017020172

46. Nakajima H, Hirose K. Role of IL-23 and Th17 cells in airway inflammation in asthma. Immune Netw. 2010;10(1):1-4. https://doi.org/10.4110/in.2010.10.1.1

47. Guerra ES, Lee CK, Specht CA, Yadav B, Huang H, Akalin $A$, et al. Central role of IL-23 and IL-17 producing eosinophils as immunomodulatory effector cells in acute pulmonary aspergillosis and allergic asthma. PLoS Pathog. 2017;13(1):e1006175-e1006175. https://doi.org/10.1371/journal.ppat. 1006175

48. Cheung PFY, Wong CK, Lam CWK. Molecular mechanisms of cytokine and chemokine release from eosinophils activated by IL-17A, IL-17F, and IL-23: implication for Th17 lymphocytes-mediated allergic inflammation. J Immunol. 2008;180(8):5625-5635. https://doi.org/10.4049/ jimmunol.180.8.5625

49. Esnault S, Kelly EAB, Nettenstrom LM, Cook EB, Seroogy CM, Jarjour NN. Human eosinophils release IL-1B and increase expression of IL-17A in activated CD4+ $T$ lymphocytes. Clin Exp Allergy. 2012;42(12):1756-1764. https://doi. org/10.1111/j.1365-2222.2012.04060.x

50. Louten J, Boniface K, de Waal Malefyt R. Development and function of TH17 cells in health and disease. J Allergy Clin Immunol. 2009;123(5):1004-1011. https://doi.org/10.1016/j. jaci.2009.04.003

51. Ota K, Kawaguchi M, Matsukura S, Kurokawa M, Kokubu F, Fujita J, et al. Potential involvement of IL-17F in 
asthma. J Immunol Res. 2014;2014:602846. https://doi. org/10.1155/2014/602846

52. Bandeira-Melo C, Sugiyama K, Woods LJ, Phoofolo M, Center DM, Cruikshank WW, et al. IL-16 promotes leukotriene $\mathrm{C} 4$ and IL-4 release from human eosinophils via CD4- and autocrine CCR3-chemokine-mediated signaling. J Immunol. 2002;168(9):4756-4763. https://doi.org/10.4049/ jimmunol.168.9.4756

53. Deo SS, Mistry KJ, Kakade AM, Niphadkar PV. Role played by Th2 type cytokines in IgE mediated allergy and asthma. Lung India. 2010;27(2):66-71. https://doi. org /10.4103/0970-2113.63609

54. Petty HR, Worth RG, Todd RF. Interactions of integrins with their partner proteins in leukocyte membranes. Immunol Res. 2002;25(1):75-96. https://doi.org/10.1385/IR:25:1:75

55. Johansson MW, Annis DS, Mosher DF. $\alpha(M) \beta(2)$ integrin-mediated adhesion and motility of IL-5-stimulated eosinophils on periostin. Am J Respir Cell Mol Biol. 2013;48(4):503-510. https://doi.org/10.1165/rcmb.2012-01500C

56. Kaneko M, Horie S, Kato M, Gleich GJ, Kita H. A crucial role for beta 2 integrin in the activation of eosinophils stimulated by IgG. J Immunol, 1995;155(5):2631-2641.

57. Park BL, Kim LH, Choi YH, et al. Interleukin 3 (IL3) polymorphisms associated with decreased risk of asthma and atopy. J Hum Genet. 2004;49(10):517-527. https://doi.org/10.1007/ s10038-004-0184-x

58. Schroeder JT, Chichester KL, Bieneman AP. Human basophils secrete IL-3: evidence of autocrine priming for phenotypic and functional responses in allergic disease. J Immunol. 2009;182(4):2432-2438. https://doi.org/10.4049/ jimmunol.0801782

59. Dougan M, Dranoff G, Dougan SK. GM-CSF, IL-3, and IL-5 family of cytokines: regulators of inflammation. Immunity. 2019;50(4):796-811. https://doi.org/10.1016/j. immuni.2019.03.022

60. Esnault S, Kelly EAB, Shen Z-J, Johansson MW, Malter JS, Jarjour NN. IL-3 maintains activation of the p90S6K/RPS6 pathway and increases translation in human eosinophils. J Immunol. 2015;195(6):2529-2539. https://doi.org/10.4049/ jimmunol.1500871

61. Esnault S, Kelly EA, Johansson MW, Liu LY, Han ST, Akhtar $M$, et al. Semaphorin 7A is expressed on airway eosinophils and upregulated by IL- 5 family cytokines. Clin Immunol. 2014;150(1):90-100. https://doi.org/10.1016/j. clim.2013.11.009

62. Esnault S, Johansson MW, Kelly EA, Koenderman L, Mosher DF, Jarjour NN. IL-3 up-regulates and activates human eosinophil CD32 and $\mathrm{aM} \beta 2$ integrin causing degranulation. Clin Exp Allergy. 2017;47(4):488-498. https://doi. org/10.1111/cea.12876

63. Mou Z, Xia J, Tan Y, Wang X, Zhang Y, Zhou B, et al. Overexpression of thymic stromal lymphopoietin in allergic rhinitis. Acta Otolaryngol. 2009;129(3):297-301. https://doi. org/10.1080/00016480802225884

64. Szefler SJ, Wenzel S, Brown R, Erzurum SC, Fahy JV, Hamilton RG, et al. Asthma outcomes: biomarkers. J Allergy Clin Immunol. 2012;129(3 Suppl):S9-S23. https://doi. org/10.1016/j.jaci.2011.12.979

65. Matsuda A, Ebihara N, Yokoi N, Kawasaki S, Tanioka H, Inatomi $\mathrm{T}$, et al. Functional role of thymic stromal lymphopoietin in chronic allergic keratoconjunctivitis. Investig Opthalmology Vis Sci. 2010;51(1):151. https://doi.org/10.1167/ iovs.09-4183

66. Cook EB, Stahl JL, Schwantes EA, Fox KE, Mathur SK. IL-3 and TNFa increase Thymic Stromal Lymphopoietin Receptor (TSLPR) expression on eosinophils and enhance TSLPstimulated degranulation. Clin Mol Allergy. 2012;10(1):8. https://doi.org/10.1186/1476-7961-10-8
67. Ito $\mathrm{T}$, Wang $\mathrm{YH}$, Duramad $\mathrm{O}$, Hori $\mathrm{T}$, Delespesse $\mathrm{GJ}$, Watanabe $\mathrm{N}$, et al. TSLP-activated dendritic cells induce an inflammatory $\mathrm{T}$ helper type 2 cell response through OX40 ligand. J Exp Med. 2005;202(9):1213-1223. https://doi. org/10.1084/jem.20051135

68. Kita H, Weiler DA, Abu-Ghazaleh R, Sanderson CJ, Gleich GJ. Release of granule proteins from eosinophils cultured with IL-5. J Immunol, 1992;149(2):629-635.

69. Tedla N, Bandeira-Melo C, Tassinari P, Sloane DE, Samplaski $M$, Cosman D, et al. Activation of human eosinophils through leukocyte immunoglobulin-like receptor 7. Proc Natl Acad Sci U S A. 2003;100(3):1174-1179. https://doi.org/10.1073/ pnas. 0337567100

70. Schweizer RC, van Kessel-Welmers BA, Warringa RA, Maikoe T, Raaijmakers JA, Lammers JW, et al. Mechanisms involved in eosinophil migration. Platelet-activating factor-induced Chemotaxis and interleukin-5-induced chemokinesis are mediated by different signals. J Leukoc Biol. 1996;59(3):347356. https://doi.org/10.1002/jlb.59.3.347

71. Tamura N, Agrawal DK, Suliaman FA, Townley RG. Effects of platelet activating factor on the chemotaxis of normodense eosinophils from normal subjects. Biochem Biophys Res Commun. 1987;142(3):638-644. https://doi. org/10.1016/0006-291X(87)91462-8

72. Chung KF, Barnes PJ. Role for platelet-activating factor in asthma. Lipids. 1991;26(12):1277-1279. https://doi. org/10.1007/BF02536547

73. Kimani G, Tonnesen MG, Henson PM. Stimulation of eosinophil adherence to human vascular endothelial cells in vitro by platelet-activating factor. J Immunol, 1988;140(9):3161-3166.

74. Kato M, Kita H, Tachibana A, Hayashi Y, Tsuchida Y, Kimura $\mathrm{H}$. Dual signaling and effector pathways mediate human eosinophil activation by platelet-activating factor. Int Arch Allergy Immunol. 2004;134(1):37-43. https://doi. org/10.1159/000077791

75. Emery DL, Djokic TD, Graf PD, Nadel JA. Prostaglandin D2 causes accumulation of eosinophils in the lumen of the dog trachea. J Appl Physiol. 1989;67(3):959-962. https://doi. org/10.1152/jappl.1989.67.3.959

76. Monneret G, Cossette C, Gravel S, Rokach J, Powell WS. 15R-Methyl-prostaglandin D2 is a potent and selective CRTH2/DP2 receptor agonist in human eosinophils. J Pharmacol Exp Ther. 2003;304(1):349-355. https://doi. org/10.1124/jpet.102.042937

77. Sawyer N, Cauchon E, Chateauneuf A, Cruz RP, Nicholson DW, Metters KM, et al. Molecular pharmacology of the human prostaglandin D2 receptor, CRTH2. Br J Pharmacol. 2002;137(8):1163-1172. https://doi.org/10.1038/sj.bjp.0704973

78. Schwingshackl A, Duszyk M, Brown N, Moqbel R. Human eosinophils release matrix metalloproteinase-9 on stimulation with TNF-a. J Allergy Clin Immunol. 1999;104(5):983990. https://doi.org/10.1016/S0091-6749(99)70079-5

79. DiScipio RG, Schraufstatter IU, Sikora L, Zuraw BL, Sriramarao P. C5a mediates secretion and activation of matrix metalloproteinase 9 from human eosinophils and neutrophils. Int Immunopharmacol. 2006;6(7):1109-1118. https:// doi.org/10.1016/j.intimp.2006.02.006

80. Vu TH. Matrix metalloproteinases: effectors of development and normal physiology. Genes Dev. 2000;14(17):2123-2133. https://doi.org/10.1101/gad.815400

81. McMillan SJ, Kearley J, Campbell JD, Zhu XW, Larbi KY, Shipley JM, et al. Matrix metalloproteinase- 9 deficiency results in enhanced allergen-induced airway inflammation. J Immunol. 2004;172(4):2586-2594. https://doi.org/10.4049/ jimmunol.172.4.2586

82. Ingram J, Kraft M. Metalloproteinases as modulators of allergic asthma: therapeutic perspectives. Met Med. 2015;2:6174. https://doi.org/10.2147/MNM.S63614 
83. Ohbayashi H, Shimokata K. Matrix metalloproteinase-9 and airway remodeling in asthma. Curr Drug Target Inflammation Allergy. 2005;4(2):177-181. https://doi. org/10.2174/1568010053586246

84. Hallsworth MP, Twort CH, Lee TH, Hirst SJ. Beta(2)adrenoceptor agonists inhibit release of eosinophil-activating cytokines from human airway smooth muscle cells. $\mathrm{Br}$ J Pharmacol. 2001;132(3):729-741. https://doi.org/10.1038/ sj.bjp.0703866

85. Lazzeri N, Belvisi MG, Patel HJ, Yacoub MH, Fan Chung K, Mitchell JA. Effects of prostaglandin E2 and cAMP elevating drugs on GM-CSF release by cultured human airway smooth muscle cells. Am J Respir Cell Mol Biol. 2001;24(1):44-48. https://doi.org/10.1165/ajrcmb.24.1.4027

86. Toda A, Yokomizo T, Shimizu T. Leukotriene B4 receptors. Prostaglandins Other Lipid Mediat. 2002;68-69:575-585. https://doi.org/10.1016/S0090-6980(02)00056-4

87. Kelly EAB, Liu LY, Esnault S, Quinchia Johnson BH, Jarjour NN. Potent synergistic effect of IL-3 and TNF on matrix metalloproteinase 9 generation by human eosinophils. Cytokine. 2012;58(2):199-206. https://doi.org/10.1016/j. cyto.2012.01.009

88. Kelly EA, Esnault S, Johnson SH, Liu LY, Malter JS, Burnham $M E$, et al. Human eosinophil activin A synthesis and mRNA stabilization are induced by the combination of IL-3 plus TNF. Immunol Cell Biol. 2016;94(7):701-708. https://doi. org/10.1038/icb.2016.30

89. Wong CK, Ip WK, Lam CWK. Interleukin-3, -5, and granulocyte macrophage colony-stimulating factor-induced adhesion molecule expression on eosinophils by p38 mitogen-activated protein kinase and nuclear factor- $\mathrm{kB}$. Am J Respir Cell Mol Biol. 2003;29(1):133-147. https://doi.org/10.1165/ rcmb.2002-02890C

90. Wong GW, Li ST, Hui DS, Fok TF, Zhong NS, Chen YZ, et al. Individual allergens as risk factors for asthma and bronchial hyperresponsiveness in Chinese children. Eur Respir J. 2002;19(2):288-293. https://doi.org/10.1183/09031936.02.002 319.02

91. Wong CK, Wang CB, Ip WK, Tian YP, Lam CWK. Role of p38 MAPK and NF-kB for chemokine release in coculture of human eosinophils and bronchial epithelial cells. Clin Exp Immunol. 2005;139(1):90-100. https://doi. org/10.1111/j.1365-2249.2005.02678.x

92. Jose PJ, Griffiths-Johnson DA, Collins PD, Walsh DT, Moqbel R, Totty NF, et al. Eotaxin: a potent eosinophil chemoattractant cytokine detected in a guinea pig model of allergic airways inflammation. J Exp Med. 1994;179(3):881-887. https:// doi.org/10.1084/jem.179.3.881

93. Lloyd C. Chemokines in allergic lung inflammation. Immunol. 2002;105(2):144-154. https://doi.org/10.1046/j.1365-2567. 2002.01344.x

94. Humbles AA, Conroy DM, Marleau S, Rankin SM, Palframan RT, Proudfoot $\mathrm{AE}$, et al. Kinetics of eotaxin generation and its relationship to eosinophil accumulation in allergic airways disease: analysis in a guinea pig model in vivo. J Exp Med. 1997;186(4):601-612. https://doi.org/10.1084/jem.186.4.601

95. Kitaura M, Nakajima T, Imai T, Harada S, Combadiere C, Tiffany $\mathrm{HL}$, et al. Molecular cloning of human eotaxin, an eosinophil-selective CC chemokine, and identification of a specific eosinophil eotaxin receptor, CC chemokine receptor 3. J Biol Chem. 1996;271(13):7725-7730. https://doi. org $/ 10.1074 / j b c .271 .13 .7725$

96. Uguccioni M, Mackay CR, Ochensberger B, Loetscher P, Rhis S, LaRosa GJ, et al. High expression of the chemokine receptor CCR3 in human blood basophils. Role in activation by eotaxin, MCP-4, and other chemokines. J Clin Invest. 1997;100(5):1137-1143. https://doi.org/10.1172/JCl119624
97. Nakajima H, Gleich GJ, Kita H. Constitutive production of IL-4 and IL-10 and stimulated production of IL- 8 by normal peripheral blood eosinophils. J Immunol. 1996;156(12):4859-4866.

98. El-Shazly A, Yamaguchi N, Masuyama K, Suda T, Ishikawa T. Novel association of the Src family kinases, Hck and c-Fgr, with CCR3 receptor stimulation: a possible mechanism for eotaxin-induced human eosinophil chemotaxis. Biochem Biophys Res Commun. 1999;264(1):163-170. https://doi.org/ 10.1006/bbrc.1999.1379

99. Lee MH, Choi JW, Jang WR, Kim JM, Kim JH. Activation of eosinophils is more closely linked with interleukin-5 and nitric oxide production than tumor necrosis factor-a and immunoglobulin E levels. Acta Haematol. 2013;130(4):238241. https://doi.org/10.1159/000350474

100. Mashaghi A, Marmalidou A, Tehrani M, Grace PM, Pothoulakis C, Dana R. Neuropeptide substance $P$ and the immune response. Cell Mol Life Sci. 2016;73(22):4249-4264. https:// doi.org/10.1007/s00018-016-2293-z

101. Ziche M, Morbidelli L, Parenti A, Amerini S, Granger HJ, Maggi CA. Substance P increases cyclic GMP levels on coronary postcapillary venular endothelial cells. Life Sci. 1993;53(14):PL229-PL234. https://doi.org/10.1016/00243205(93)90556-।

102. Nguyen LS, Villablanca AC, Rutledge JC. Substance $P$ increases microvascular permeability via nitric oxidemediated convective pathways. Am J Physiol Integr Comp Physiol. 1995;268(4):R1060-R1068. https://doi.org/10.1152/ ajpregu.1995.268.4.R1060

103. Kroegel C, Giembycz MA, Barnes PJ. Characterization of eosinophil cell activation by peptides. Differential effects of substance P, melittin, and FMET-Leu-Phe. J Immunol. 1990;145:2581-2587.

104. Moncada SR. Nitric oxide: physiology, pathophysiology and pharmacology. Pharmacol Rev. 1991;43:109-142.

105. Moncada S, Higgs A. The L-arginine-nitric oxide pathway. N Engl J Med. 1993;329:2002-2012. https://doi.org/10.1056/ NEJM199312303292706

106. Prado CM, Martins MA, Tibério IFLC. Nitric oxide in asthma physiopathology. ISRN Allergy. 2011;2011:832560. https://doi. org $/ 10.5402 / 2011 / 832560$

107. Hynes RO. Integrins. Cell. 2002;110(6):673-687. https://doi. org/10.1016/S0092-8674(02)00971-6

108. Hogan SP, Rosenberg HF, Moqbel R, Phipps S, Foster PS, Lacy $P$, et al. Eosinophils: biological properties and role in health and disease. Clin Exp Allergy. 2008;38(5):709-750. https://doi.org/10.1111/j.1365-2222.2008.02958.x

109. Barthel SR, Jarjour NN, Mosher DF, Johansson MW. Dissection of the hyperadhesive phenotype of airway eosinophils in asthma. Am J Respir Cell Mol Biol. 2006;35(3):378-386. https://doi.org/10.1165/rcmb.2006-00270C

110. Barthel SR, Johansson MW, MCNamee DM, Mosher DF. Roles of integrin activation in eosinophil function and the eosinophilic inflammation of asthma. J Leukoc Biol. 2008;83(1):112. https://doi.org/10.1189/jlb.0607344

111. Banerjee ER, Jiang Y, Henderson Jr WR, Latchman $Y$, Papayannopoulou T. Absence of alpha 4 but not beta 2 integrins restrains development of chronic allergic asthma using mouse genetic models. Exp Hematol. 2009;37(6):715.e3-727.e3. https://doi.org/10.1016/j.exphem.2009.03.010

112. Takaku Y, Nakagome K, Kobayashi T, Hagiwara K, Kanazawa $M$, Nagata M. IFN- $\gamma$-inducible protein of $10 \mathrm{kDa}$ upregulates the effector functions of eosinophils through $\beta 2$ integrin and CXCR3. Respir Res. 2011;12(1):138. https://doi. org/10.1186/1465-9921-12-138

113. McEver RP, Beckstead JH, Moore KL, Marshall-Carlson L, Bainton DF. GMP-140, a platelet alpha-granule membrane protein, is also synthesized by vascular endothelial cells 
and is localized in Weibel-Palade bodies. J Clin Invest. 1989;84(1):92-99. https://doi.org/10.1172/JCl114175

114. Andre $\mathrm{P}$. P-selectin in haemostasis. $\mathrm{Br} \mathrm{J}$ Haematol. 2004;126(3):298-306. https://doi.org/10.1111/j.1365-2141. 2004.05032.x

115. Kappelmayer J, Nagy B, Miszti-Blasius K, Hevessy Z, Setiadi H. The emerging value of P-selectin as a disease marker. Clin Chem Lab Med. 2004;42(5):475-486. https://doi.org/10.1515/ CCLM.2004.082

116. Johansson MW, Mosher DF. Activation of beta1 integrins on blood eosinophils by P-selectin. Am J Respir Cell Mol Biol. 2011;45(4):889-897. https://doi.org/10.1165/ rcmb.2010-04020C

117. Epstein FH, Lewis RA, Austen KF, Soberman RJ. Leukotrienes and other products of the 5-lipoxygenase pathway. N Engl J Med. 1990;323(10):645-655. https://doi.org/10.1056/ NEJM199009063231006

118. Laitinen LA, Haahtela T, Vilkka V, Lee TH, Spur BW. Leukotriene E4 and granulocytic infiltration into asthmatic airways. Lancet. 1993;341(8851):989-990. https://doi. org/10.1016/0140-6736(93)91073-U

119. Ahmad A, Shameem M, Husain Q. Relation of oxidant-antioxidant imbalance with disease progression in patients with asthma. Ann Thorac Med. 2012;7(4):226-232. https://doi. org/10.4103/1817-1737.102182

120. Nadeem A, Raj HG, Chhabra SK. Increased oxidative stress in acute exacerbations of asthma. J Asthma. 2005;42(1):45-50. https://doi.org/10.1081/JAS-200044774

121. Dworski R. Oxidant stress in asthma. Thorax. 2000;55(Suppl 2):S51-S53. https://doi.org/10.1136/thorax.55.suppl_2.S51

122. Kanazawa H, Kurihara N, Hirata K, Takeda T. The role of free radicals in airway obstruction in asthmatic patients. Chest. 1991;100(5):1319-1322. https://doi.org/10.1378/ chest.100.5.1319

123. Sanders SP, Zweier JL, Harrison SJ, Trush MA, Rembish SJ, Liu MC. Spontaneous oxygen radical production at sites of antigen challenge in allergic subjects. Am J Respir Crit Care Med. 1995;151(6):1725-1733. https://doi.org/10.1164/ ajrccm.151.6.7767513

124. Vedel-Krogh S, Fallgaard Nielsen S, Lange P, Vestbo J, Nordestgaard BG. Association of blood eosinophil and blood neutrophil counts with asthma exacerbations in the Copenhagen general population study. Clin Chem. 2017;63(4):823-832. https://doi.org/10.1373/clinchem.2016. 267450

125. De Raeve HR, Thunnissen FB, Kaneko FT, Guo FH, Lewis M, Kavuru MS, et al. Decreased Cu,Zn-SOD activity in asthmatic airway epithelium: correction by inhaled corticosteroid in vivo. Am J Physiol Cell Mol Physiol. 1997;272(1):L148-L154. https://doi.org/10.1152/ajplung.1997.272.1.L148

126. Jatakanon A, Uasuf C, Maziak W, Lim SAM, Chung KF, Barnes PJ. Neutrophilic inflammation in severe persistent asthma. Am J Respir Crit Care Med. 1999;160(5):1532-1539. https:// doi.org/10.1164/ajrccm.160.5.9806170

127. MacPherson JC, Comhair SA, Erzurum SC, Klein DF, Lipscomb MF, Kavuru MS, et al. Eosinophils are a major source of nitric oxide-derived oxidants in severe asthma: characterization of pathways available to eosinophils for generating reactive nitrogen species. J Immunol. 2001;166(9):5763-5772. https:// doi.org/10.4049/jimmunol.166.9.5763

128. Wu W, Samoszuk MK, Comhair SA, Thomassen MJ, Farver CF, Dweik RA, et al. Eosinophils generate brominating oxidants in allergen-induced asthma. J Clin Invest. 2000;105(10):14551463. https://doi.org/10.1172/JCI9702

129. Bozeman PM, Learn DB, Thomas EL. Assay of the human leukocyte enzymes myeloperoxidase and eosinophil peroxidase. J Immunol Methods. 1990;126(1):125-133. https://doi. org/10.1016/0022-1759(90)90020-V
130. Honda K, Chihara J. Eosinophil activation by eotaxin-eotaxin primes the production of reactive oxygen species from eosinophils. Allergy. 1999;54(12):1262-1269. https://doi. org/10.1034/j.1398-9995.1999.00170.x

131. Fischkoff SA. Graded increase in probability of eosinophilic differentiation of $\mathrm{HL}-60$ promyelocytic leukemia cells induced by culture under alkaline conditions. Leuk Res. 1988;12(8):679686. https://doi.org/10.1016/0145-2126(88)90103-8

132. Lopez JA, Newburger PE, Condino-Neto A. The effect of IFN-yand TNF-a on the eosinophilic differentiation and NADPH oxidase activation of human HL-60 clone 15 cells. J Interf Cytokine Res. 2003;23(12):737-744. https://doi. org/10.1089/107999003772084851

133. Badewa AP, Hudson CE, Heiman AS. Regulatory effects of eotaxin, eotaxin-2, and eotaxin-3 on eosinophil degranulation and superoxide anion generation 1. Exp Biol Med. 2002;227(8):645-651. https://doi. org/10.1177/153537020222700814

134. Zimmermann N, Daugherty BL, Stark JM, Rothenberg ME. Molecular analysis of CCR-3 events in eosinophilic cells. J Immunol. 2000;164(2):1055-1064. https://doi.org/10.4049/ jimmunol.164.2.1055

135. Tiffany HL, Alkhatib G, Combadiere C, Berger EA, Murphy PM. CC chemokine receptors 1 and 3 are differentially regulated by IL- 5 during maturation of eosinophilic HL-60 cells. J Immunol. 1998;160:1385-1392.

136. Woschnagg C, Garcia R, Rak S, Venge P. IL-5 priming of the PMA-induced oxidative metabolism of human eosinophils from allergic and normal subjects during a pollen season. Clin Exp Allergy. 2001;31(4):555-564. https://doi. org/10.1046/j.1365-2222.2001.00995.x

137. Lavinskiene S, Malakauskas K, Jeroch J, Hoppenot D, Sakalauskas R. Functional activity of peripheral blood eosinophils in allergen-induced late-phase airway inflammation in asthma patients. J Inflamm (Lond). 2015;12:25. https://doi. org/10.1186/s12950-015-0065-4

138. Ahluwalia J, Tinker A, Clapp LH, Duchen MR, Abramov AY, Pope S, et al. The large-conductance Ca2+-activated $\mathrm{K}_{+}$channel is essential for innate immunity. Nature. 2004;427(6977):853-858. https://doi.org/10.1038/ nature 02356

139. Thompson NT, Tateson JE, Randall RW, Spacey GD, Bonser RW, Garland LG. The temporal relationship between phospholipase activation, diradylglycerol formation and superoxide production in the human neutrophil. Biochem J. 1990;271(1):209-213. https://doi.org/10.1042/bj2710209

140. Kessels GC, Roos D, Verhoeven AJ. fMet-Leu-Phe-induced activation of phospholipase $D$ in human neutrophils. Dependence on changes in cytosolic free $\mathrm{Ca} 2+$ concentration and relation with respiratory burst activation. J Biol Chem. 1991;266:23152-23156

141. Kita H, Abu-Ghazaleh RI, Gleich GJ, Abraham RT. Role of pertussis toxin-sensitive $G$ proteins in stimulus-dependent human eosinophil degranulation. J Immunol. 1991; 147:3466-3473.

142. Wan $Y$, Kurosaki T, Huang $X-Y$. Tyrosine kinases in activation of the MAP kinase cascade by G-protein-coupled receptors. Nature. 1996;380(6574):541-544. https://doi. org $/ 10.1038 / 380541 \mathrm{aO}$

143. Schwingshackl A, Moqbel R, Duszyk M. Involvement of ion channels in human eosinophil respiratory burst. J Allergy Clin Immunol. 2000;106(2):272-279. https://doi.org/10.1067/ mai.2000.107752

144. Steinberg SF. Structural basis of protein kinase $C$ isoform function. Physiol Rev. 2008;88(4):1341-1378. https://doi. org/10.1152/physrev.00034.2007

145. Stolarski B, Kurowska-Stolarska M, Kewin P, Xu D, Liew FY. IL-33 Exacerbates eosinophil-mediated airway inflammation. 
J Immunol. 2010;185(6):3472-3480. https://doi.org/10.4049/ jimmunol.1000730

146. Someya A, Nishijima K, Nunoi H, Irie S, Nagaoka I. Study on the superoxide-producing enzyme of eosinophils and neutrophils-comparison of the NADPH oxidase components. Arch Biochem Biophys. 1997;345(2):207-213. https://doi. org/10.1006/abbi.1997.0252

147. Aldridge RE, Chan T, van Dalen CJ, Senthilmohan R, Winn M, Venge $P$, et al. Eosinophil peroxidase produces hypobromous acid in the airways of stable asthmatics. Free Radic Biol Med. 2002;33(6):847-856. https://doi.org/10.1016/ S0891-5849(02)00976-0

148. Shayma'a J. Raisan, Muna H. Sadeq. Myeloperoxidase (MPO) and eosinophil peroxidase (EPO) effecting on asthma patients in Basra Province, Iraq. Biomed Res. 2018;29(17: 3395-3397. https://doi.org/10.4066/biomedicalresearch.29-18-1024

149. Mitra SN, Slungaard A, Hazen SL. Role of eosinophil peroxidase in the origins of protein oxidation in asthma. Redox Rep. 2000;5(4):215-224. https://doi. org/10.1179/135100000101535771

150. Brennan ML, Wu W, Fu X, Shen Z, Song W, Frost $H$, et al. A tale of two controversies (defining both the role of peroxidases in nitrotyrosine formation in vivo using eosinophil peroxidase and myeloperoxidase-deficient mice, and the nature of peroxidase-generated reactive nitrogen species). J Biol Chem. 2002;277(20):17415-17427. https://doi.org/10.1074/ jbc.M112400200

151. Erzurum SC. New insights in oxidant biology in asthma. Ann Am Thorac Soc. 2016;13:S35-S39.

152. Kaminsky DA, Mitchell J, Carroll N, James A, Soultanakis $R$, Janssen $Y$. Nitrotyrosine formation in the airways and lung parenchyma of patients with asthma. J Allergy Clin Immunol. 1999;104(4):747-754. https://doi.org/10.1016/ S0091-6749(99)70283-6

153. Saleh D, Ernst P, Lim S, Barnes PJ, Giaid A. Increased formation of the potent oxidant peroxynitrite in the airways of asthmatic patients is associated with induction of nitric oxide synthase: effect of inhaled glucocorticoid. FASEB J. 1998;12(11):929-937. https://doi.org/10.1096/fasebj.12.11.929

154. Hirai H, Tanaka K, Yoshie O, et al. Prostaglandin D2 selectively induces chemotaxis in $\mathrm{T}$ helper type 2 cells, eosinophils, and basophils via seven-transmembrane receptor CRTH2. J Exp Med. 2001;193(2):255-261. https://doi. org/10.1084/jem.193.2.255

155. Royer JF, Schratl P, Lorenz S, Kostenis E, Ulven T, Schuligoi $\mathrm{R}$, et al. A novel antagonist of CRTH2 blocks eosinophil release from bone marrow, chemotaxis and respiratory burst. Allergy. 2007;62(12):1401-1409. https://doi. org/10.1111/j.1398-9995.2007.01452.x

156. Horiuchi T, Weller PF. Expression of vascular endothelial growth factor by human eosinophils: upregulation by granulocyte macrophage colony-stimulating factor and interleukin-5. Am J Respir Cell Mol Biol. 1997;17(1):70-77. https://doi. org/10.1165/ajrcmb.17.1.2796

157. Sexton DW, Blaylock MG, Walsh GM. Human alveolar epithelial cells engulf apoptotic eosinophils by means of integrin- and phosphatidylserine receptor-dependent mechanisms: a process upregulated by dexamethasone. J Allergy Clin Immunol. 2001;108(6):962-969. https://doi.org/10.1067/mai.2001.119414

158. Oddera S, Silvestri M, Balbo A, Jovovich BO, Penna R, Grimi $\mathrm{E}$, et al. Airway eosinophilic inflammation, epithelial damage, and bronchial hyperresponsiveness in patients with mild-moderate, stable asthma. Allergy. 1996;51(2):100-107. https://doi.org/10.1111/j.1398-9995.1996.tb04565.x; https:// doi.org/10.1111/j.1398-9995.1996.tb00042.x

159. Kuperman DA, Huang X, Koth LL, Chang GH, Dolganov GM, Zhu Z, et al. Direct effects of interleukin-13 on epithelial cells cause airway hyperreactivity and mucus overproduction in asthma. Nat Med. 2002;8(8):885-889. https://doi. org/10.1038/nm734

160. Lankford SM, Macchione M, Crews AL, Mckane SA, Akley NJ, Martin LD. Modeling the airway epithelium in allergic asthma: interleukin-13-induced effects in differentiated murine tracheal epithelial cells. In Vitro Cell Dev Biol Anim. 2005;41:217-224. https://doi.org/10.1290/0502012.1

161. Shi HZ, Humbles A, Gerard C, Jin Z, Weller PF. Lymph node trafficking and antigen presentation by endobronchial eosinophils. J Clin Invest. 2000;105(7):945-953. https://doi. org/10.1172/JCl8945

162. Deshmane SL, Kremlev S, Amini S, Sawaya BE. Monocyte chemoattractant protein-1 (MCP-1): an overview. J Interferon Cytokine Res. 2009;29(6):313-326. https://doi.org/10.1089/ jir.2008.0027

163. Kalluri R, Neilson EG. Epithelial-mesenchymal transition and its implications for fibrosis. J Clin Invest. 2003;112(12):17761784. https://doi.org/10.1172/JCI200320530

164. Royce SG, Cheng V, Samuel CS, Tang MLK. The regulation of fibrosis in airway remodeling in asthma. Mol Cell Endocrinol. 2012;351(2):167-175. https://doi.org/10.1016/j. mce.2012.01.007

165. Redington AE, Madden J, Frew AJ, Djukanovic R, Roche WR, Holgate ST, et al. Transforming growth factor- $\beta 1$ in Asthma. Am J Respir Crit Care Med. 1997;156(2):642-647. https://doi. org/10.1164/ajrccm.156.2.9605065

166. Zhang S, Smartt H, Holgate ST, Roche WR. Growth factors secreted by bronchial epithelial cells control myofibroblast proliferation: an in vitro co-culture model of airway remodelling in asthma. Lab Invest. 1999;79:395-405.

167. Howat WJ, Holgate ST, Lackie PM. TGF- $\beta$ isoform release and activation during in vitro bronchial epithelial wound repair. Am J Physiol Cell Mol Physiol. 2002;282(1):L115-L123. https:// doi.org/10.1152/ajplung.2002.282.1.L115

168. Holgate ST, Davies DE, Puddicombe S, Richter A, Lackie P, Lordan J, Howarth P, et al. Mechanisms of airway epithelial damage: epithelial-mesenchymal interactions in the pathogenesis of asthma. Eur Respir J. 2003;22(Supplement 44):24s 29s. https://doi.org/10.1183/09031936.03.00000803

169. Yasukawa A, Hosoki K, Toda M, Miyake $Y$, Matsushima $Y$, Matsumoto T, et al. Eosinophils promote epithelial to mesenchymal transition of bronchial epithelial cells. PLoS One. 2013;8(5):e64281-e64281. https://doi.org/10.1371/journal. pone.0064281

170. Sun J, Dahlén B, Agerberth B, Haeggström JZ. The antimicrobial peptide LL-37 induces synthesis and release of cysteinyl leukotrienes from human eosinophils - implications for asthma. Allergy. 2013;68(3):304-311. https://doi.org/10.1111/ all.12087

171. Jiao D, Wong CK, Tsang MS, Chu IM, Liu D, Zhu J, et al. Activation of eosinophils interacting with bronchial epithelial cells by antimicrobial peptide LL-37: implications in allergic asthma. Sci Rep. 2017;7(1):1848. https://doi.org/10.1038/ s41598-017-02085-5

172. Chu EK, Cheng J, Foley JS, Mecham BH, Owen CA, Haley KJ, et al. Induction of the plasminogen activator system by mechanical stimulation of human bronchial epithelial cells. Am J Respir Cell Mol Biol. 2006;35(6):628-638. https://doi. org $/ 10.1165 / \mathrm{rcmb} .2006-00400 \mathrm{C}$

173. Knight DA, Holgate ST. The airway epithelium: structural and functional properties in health and disease. Respirology. 2003;8(4):432-446. https://doi. org/10.1046/j.1440-1843.2003.00493.x

174. Anderson WJ, Short PM, Williamson PA, Manoharan A, Lipworth BJ. The inverse agonist propranolol confers no corticosteroid-sparing activity in mild-to-moderate persistent asthma. Clin Sci. 2014;127(11):635-643. https://doi. org/10.1042/CS20140249 
175. Carroll CL, Bhandari A, Schramm CM, Zucker AR. Chronic inhaled corticosteroids do not affect the course of acute severe asthma exacerbations in children. Pediatr Pulmonol. 2006;41(12):1213-1217. https://doi.org/10.1002/ppul.20521

176. Wenzel SE. Asthma phenotypes: the evolution from clinical to molecular approaches. Nat Med. 2012;18(5):716-725. https://doi.org/10.1038/nm.2678

177. de Groot JC, Ten Brinke A, Bel EHD. Management of the patient with eosinophilic asthma: a new era begins. ERJ open Res. 2015;1(1):00024-2015. https://doi. org/10.1183/23120541.00024-2015

178. Stelmach I, Jerzynska J, Kuna P. A randomized, double-blind trial of the effect of glucocorticoid, antileukotriene and b beta-agonist treatment on IL-10 serum levels in children with asthma. Clin Exp Allergy. 2002;32(2):264-269. https://doi. org/10.1046/j.1365-2222.2002.01286.x

179. Taylor IK, O’Shaughnessy KM, Fuller RW, Dollery C. Effect of cysteinyl-leukotriene receptor antagonist ICl 204.219 on allergen-induced bronchoconstriction and airway hyperreactivity in atopic subjects. Lancet. 1991;337(8743):690-694. https://doi.org/10.1016/0140-6736(91)90277-V

180. Morina N, Boçari G, Iljazi A, Hyseini K, Halac G. Maximum time of the effect of antileukotriene-zileuton in treatment of patients with bronchial asthma. Acta Inform Med. 2016;24(1):16-19. https://doi.org/10.5455/aim.2016.24.16-19

181. Ibe BO, Portugal AM, Raj JU. Levalbuterol inhibits human airway smooth muscle cell proliferation: therapeutic implications in the management of asthma. Int Arch Allergy Immunol. 2006;139(3):225-236. https://doi.org/10.1159/000091168

182. Špadijer Mirković C, Perić A, Vukomanović Đurđević B, Vojvodić D. Effects of fluticasone furoate nasal spray on parameters of eosinophilic inflammation in patients with nasal polyposis and perennial allergic rhinitis. Ann Otol Rhinol Laryngol. 2017;126(8):573-580. https://doi. org/10.1177/0003489417713505

183. Peter Gruber, Hans Joachim Lach, Norbert Otterbeck, "Budesonide pellets with a controlled released pattern and process for producing the same.” U.S. Patent US5932249, issued May, 1991.

184. Pui-Ho Yuen, Charles Eckhart, Teresa Etlinger, Nancy Levine. "Mometasone furoate monohydrate, process for making same and pharmaceutical compositions." U.S. Patent US6127353, issued April, 1988. https://doi.org/10.18578/BNF.213416560

185. Trescoli C, Ward MJ. Systemic activity of inhaled and swallowed beclomethasone dipropionate and the effect of different inhaler devices. Postgrad Med J. 1998;74(877):675-677. https://doi.org/10.1136/pgmj.74.877.675

186. Wilcox JB, Avery GS. Beclomethasone dipropionate corticosteroid inhaler. Drugs. 1973;6(2):84-93. https://doi. org/10.2165/00003495-197306020-00002

187. Mutch E, Nave R, McCracken N, Zech K, Williams FM. The role of esterases in the metabolism of ciclesonide to desisobutyryl-ciclesonide in human tissue. Biochem Pharmacol. 2007;73(10):1657-1664. https://doi.org/10.1016/j. bcp.2007.01.031

188. Castro-Rodriguez JA, Rodriguez-Martinez CE, Ducharme FM. Daily inhaled corticosteroids or montelukast for preschoolers with asthma or recurrent wheezing: a systematic review. Pediatr Pulmonol. 2018;53(12):1670-1677. https://doi. org/10.1002/ppul.24176

189. Piatti G. Effects of zafirlukast on bronchial asthma and allergic rhinitis. Pharmacol Res. 2003;47(6):541-547. https://doi. org/10.1016/S1043-6618(03)00017-3

190. FDA (https://www.accessdata.fda.gov/drugsatfda_docs/ label/2009/020547s027lbl.pdf)

191. Wenzel SE, Kamada AK. Zileuton: The first 5-lipoxygenase inhibitor for the treatment of asthma. Ann Pharmacother. 1996;30(7 8):858-864. https://doi.org/10.1177/106002809603000725
192. FDA (https://www.accessdata.fda.gov/drugsatfda_docs/ label/2005/020471s011lbl.pdf)

193. Salpeter SR, Buckley NS, Ormiston TM, Salpeter EE. Metaanalysis: effect of long-acting beta-agonists on severe asthma exacerbations and asthma-related deaths. Ann Intern Med. 2006;144(12):904-912 [Epub 2006 Jun 5]. https://doi. org/10.7326/0003-4819-144-12-200606200-00126

194. Faulds D, Hollingshead LM, Goa KL. Formoterol. Drugs. 1991;42(1):115-137. https://doi.org/10.2165/00003495199142010-00007

195. Cheer SM, Scott LJ. Formoterol. Am J Respir Med. 2002;1(4):285-300. https://doi.org/10.1007/BF03256622

196. Harrell AW, Siederer SK, Bal J, Patel NH, Young GC, Felgate $\mathrm{CC}$, et al. Metabolism and disposition of vilanterol, a long-acting $\beta 2$-adrenoceptor agonist for inhalation use in humans. Drug Metab Dispos. 2012;41(1):89-100. https://doi. org/10.1124/dmd.112.048603

197. Yano Y, Yoshida M, Hoshino S, Inoue K, Kida H, Yanagita M, et al. Anti-fibrotic effects of theophylline on lung fibroblasts. Biochem Biophys Res Commun. 2006;341(3):684-690. https:// doi.org/10.1016/j.bbrc.2006.01.018

198. Morgan DJ, Paull JD, Richmond BH, Wilson-Evered E, Ziccone SP. Pharmacokinetics of intravenous and oral salbutamol and its sulphate conjugate. Br J Clin Pharmacol. 1986;22(5):587593. https://doi.org/10.1111/j.1365-2125.1986.tb02939.x

199. Jacobson GA, Raidal S, Robson K, Narkowicz CK, Nichols DS, Haydn Walters E. Bronchopulmonary pharmacokinetics of (R)-salbutamol and (S)-salbutamol enantiomers in pulmonary epithelial lining fluid and lung tissue of horses. $\mathrm{Br} \mathrm{J}$ Clin Pharmacol. 2017;83(7):1436-1445. https://doi.org/10.1111/ bcp.13228

200. Boulton DW, Fawcett JP. The pharmacokinetics of levosalbutamol. Clin Pharmacokinet. 2001;40(1):23-40. https://doi. org/10.2165/00003088-200140010-00003

201. Rehder KJ. Adjunct therapies for refractory status asthmaticus in children. Respir Care. 2017;62(6):849-865. https://doi. org/10.4187/respcare.05174

202. www.jiaci.org/issues/vol20s1/7.pdf

203. Yasir, M., Goyal, A., Bansal, P., \& Sonthalia, S. (2020). Corticosteroid adverse effects. StatPearls [Internet]. Treasure Island (FL): StatPearls Publishing; 2020 Jan-. PMID: 30285357.

204. https://www.accessdata.fda.gov/drugsatfda_docs/anda/ 99/40287_Prednisolone_Prntlbl.pdf

205. Schwartz HJ, Blumenthal M, Brady R, Braun S, Lockey R, Myers $D$, et al. A comparative study of the clinical efficacy of nedocromil sodium and placebo. Chest. 1996;109(4):945-952. https://doi.org/10.1378/chest.109.4.945

206. Holgate S, Casale T, Wenzel S, Bousquet J, Deniz Y, Reisner $\mathrm{C}$. The anti-inflammatory effects of omalizumab confirm the central role of IgE in allergic inflammation. J Allergy Clin Immunol. 2005;115(3):459-465. https://doi.org/10.1016/j. jaci.2004.11.053

207. Garrett JK, Jameson SC, Thomson B, Collins MH, Wagoner LE, Freese DK, et al. Anti-interleukin-5 (mepolizumab) therapy for hypereosinophilic syndromes. J Allergy Clin Immunol. 2004;113(1):115-119. https://doi.org/10.1016/j.jaci.2003.10.049

208. FDA (https://www.accessdata.fda.gov/drugsatfda_docs/ label/2015/1255260rig1s000Lbl.pdf)

209. Bjermer L, Lemiere C, Maspero J, Weiss S, Zangrilli J, Germinaro M. Reslizumab for inadequately controlled asthma with elevated blood eosinophil levels. Chest. 2016;150(4):789798. https://doi.org/10.1016/j.chest.2016.03.032

210. Ghazi A, Trikha A, Calhoun WJ. Benralizumab - a humanized $\mathrm{mAb}$ to IL-5Ra with enhanced antibody-dependent cell-mediated cytotoxicity - a novel approach for the treatment of asthma. Expert Opin Biol Ther. 2012;12(1):113-118. https:// doi.org/10.1517/14712598.2012.642359 
211. Koopmans JG, Lutter R, Jansen HM, van der Zee JS. Adding salmeterol to an inhaled corticosteroid reduces allergen-induced serum IL-5 and peripheral blood eosinophils. J Allergy Clin Immunol. 2005;116(5):1007-1013. https://doi. org/10.1016/j.jaci.2005.08.016

212. Williams DM, Rubin BK. Clinical pharmacology of bronchodilator medications. Respir Care. 2018;63(6):641-654. https:// doi.org/10.4187/respcare.06051

213. Powell C, Milan SJ, Dwan K, Bax L, Walters N. Mepolizumab versus placebo for asthma. Cochrane Database of Systematic Reviews. John Wiley \& Sons, Ltd; 2015. https://doi. org/10.1002/14651858.CD010834.pub2

214. Pham T-H, Damera G, Newbold P, Ranade K. Reductions in eosinophil biomarkers by benralizumab in patients with asthma. Respir Med. 2016;111:21-29. https://doi. org/10.1016/j.rmed.2016.01.003

215. Bleecker ER, FitzGerald JM, Chanez P, Papi A, Weinstein SF, Barker P, et al. Efficacy and safety of benralizumab for patients with severe asthma uncontrolled with high-dosage inhaled corticosteroids and long-acting $\beta 2$-agonists (SIROCCO): a randomised, multicentre, placebo-controlled phase 3 trial. Lancet. 2016;388(10056):2115-2127. https://doi. org/10.1016/S0140-6736(16)31324-1

216. Nixon J, Newbold P, Mustelin T, Anderson GP, Kolbeck R. Monoclonal antibody therapy for the treatment of asthma and chronic obstructive pulmonary disease with eosinophilic inflammation. Pharmacol Ther. 2017;169:57-77. https://doi. org/10.1016/j.pharmthera.2016.10.016

217. Murphy S, Kelly HW. Cromolyn sodium: a review of mechanisms and clinical use in asthma. Drug Intell
Clin Pharm. 1987;21(1):22-35. https://doi.org/10.1177/ $10600280870211 \mathrm{P} 102$

218. Viscardi RM, Hasday JD, Gumpper KF, Taciak V, Campbell AB, Palmer TW. Cromolyn sodium prophylaxis inhibits pulmonary proinflammatory cytokines in infants at high risk for bronchopulmonary dysplasia. Am J Respir Crit Care Med. 1997;156(5):1523-1529. https://doi.org/10.1164/ ajrccm.156.5.9611088

219. Theoharides T, Sieghart W, Greengard P, Douglas W. Antiallergic drug cromolyn may inhibit histamine secretion by regulating phosphorylation of a mast cell protein. Science. 1980; 207(4426):80-82. https://doi.org/10.1126/ science. 6153130

220. Kay AB, Walsh GM, Moqbel R, MacDonald AJ, Nagakura T, Carroll MP, et al. Disodium cromoglycate inhibits activation of human inflammatory cells in vitro. J Allergy Clin Immunol. 1987;80(1):1-8. https://doi.org/10.1016/ S0091-6749(87)80183-5

221. Oka T, Kalesnikoff J, Starkl P, Tsai M, Galli SJ. Evidence questioning cromolyn's effectiveness and selectivity as a "mast cell stabilizer" in mice. Lab Invest. 2012;92(10):1472-1482. https://doi.org/10.1038/labinvest.2012.116

222. Castro M, Mathur S, Hargreave F, Boulet LP, Xie F, Young J, et al. Reslizumab for poorly controlled, eosinophilic asthma: a randomized, placebo-controlled study. Am J Respir Crit Care Med. 2011;184:1125-1113. https://doi.org/10.1164/ rccm.201103-03960C

223. Gour N, Wills-Karp M. IL-4 and IL-13 signaling in allergic airway disease. Cytokine. 2015;75(1):68-78. https://doi. org/10.1016/j.cyto.2015.05.014 